\title{
The decline of science in corporate R\&D
}

\section{Authors:}

\section{Ashish Arora}

Titles and affiliations: Rex D. Adams Professor. Fuqua School of Business, Duke University, and NBER.

Address: Duke University, Fuqua School of Business, 100 Fuqua Drive, Durham, NC 27708.

Email: ashish.arora@duke.edu

Sharon Belenzon

Titles and affiliations: Associate Professor. Fuqua School of Business, Duke University.

Address: Duke University, Fuqua School of Business, 100 Fuqua Drive, Durham, NC 27708.

Email: sharon.belenzon@duke.edu

Andrea Patacconi

Titles and affiliations: Senior Lecturer. Norwich Business School, University of East Anglia.

Address: Norwich Business School, University of East Anglia, Norwich Research Park, Norwich, NR4 7TJ, UK.

Email: A.Patacconi@uea.ac.uk

Running head: The decline of science in corporate R\&D

Keywords: innovation, scientific research, development, patents, use of science in inventions.

JEL Classification: O31, O32, O16.

This article has been accepted for publication and undergone full peer review but has not been through the copyediting, typesetting, pagination and proofreading process, which may lead to differences between this version and the Version of Record. Please cite this article as doi: $10.1002 / \mathrm{smj} .2693$ 


\section{The decline of science in corporate R\&D}

Research summary: In this paper, we document a shift away from science by large corporations between 1980 and 2006. We find that publications by company scientists have declined over time in a range of industries. We also find that the value attributable to scientific research has dropped, whereas the value attributable to technical knowledge (as measured by patents) has remained stable. These trends are unlikely to be driven principally by changes in publication practices. Further science continues to be useful as an input into innovation. Our evidence points to a reduction of the private benefits of internal research. Large firms still value the golden eggs of science (as reflected in patents) but seem to be increasingly unwilling to invest in the golden goose itself (the internal scientific capabilities).

Managerial summary: There is a widespread belief among commentators that large American corporations are withdrawing from research. Large corporations may still collaborate with universities and acquire promising science-based start-ups, but their labs increasingly focus on developing existing knowledge and commercializing it, rather than creating new knowledge. In this paper, we combine firm-level financial information with a large and comprehensive dataset on firm publications, patents and acquisitions to quantify the withdrawal from science by large American corporations between 1980 and 2006. This withdrawal is associated with a decline in the private value of research activities, even though scientific knowledge itself remains important for corporate invention. We discuss the managerial and policy implications of our findings. 


\section{Introduction}

During the 20th century and especially the post-war period, the U.S. created a scientific-industrial complex that greatly contributed to scientific progress and resulted in many important innovations. A key component of this scientific-industrial complex was the large corporate lab in corporations such as AT\&T, Du Pont, IBM and Xerox. Research from such labs has led to many important discoveries such as the transistor, the laser, and the first computer with a graphical user interface, as well as breakthroughs in medicine and pharmacology.

Since the 1980s, however, the U.S. scientific-industrial complex has undergone profound transformations (Mowery, 1995, 2009; Hounshell, 1996; Pisano, 2010). A key transformation has been the redirection, by many leading firms, of resources and attention from more exploratory scientific research toward more commercially-oriented projects. But though articles in the popular press do lament the demise of top-flight corporate labs (e.g., Economist, 2007), researchers have yet to document the breadth and depth of this transformation, or whether this decline in 'corporate science' is related to a decline in the economic value of research, and if so, whether it is private or social economic value. ${ }^{1}$

In this paper, we take a step toward filling these gaps. A fuller understanding of the nature and extent of this withdrawal is a first step towards understanding the possible reasons, such as the growth of technology markets (Arora et al., 2001; Chesbrough, 2003; Arora et al., 2016), globalization (Bloom et al. 2016; Autor et al. 2016), and managerial short-termism (e.g., Marginson and McAulay, 2008). Our findings are likely to be relevant to managers and scientific entrepreneurs, who operate within and must understand the evolution of their ecosystem (e.g., Pisano, 2010), and to policymakers, who might wish to influence it.

Our primary contribution is to establish a set of important facts about the changing nature of corporate R\&D over a quarter of a century. To do so, we develop publication-based indicators of scientific research at the firm level. We link scientific publications in "hard science" journals (including engineering science) from the Web of Science to publicly traded firms in the United States, using the affiliations of the authors. Our primary firm sample consists of 4,068 publicly listed, R\&D-performing companies with at least one patent over the period 1980-2006. Collectively, these firms account for 452,297 "firm publications" — scientific articles where at least one of the authors

\footnotetext{
${ }^{1}$ For simplicity, we use the terms "science" and "research" (or "scientific research") interchangeably. The key distinction we make is between "research" (as measured by publications in scientific journals) and "development" (as measured by patents). We largely avoid finer distinctions such as that between basic and applied research because these distinctions are often difficult to draw in practice.
}

This article is protected by copyright. All rights reserved. 
is a company employee.

We find that, over the period 1980-2006 participation in scientific research by publicly traded American companies diminished. A significant fraction of the decline can be attributed to entry by firms that do not publish or publish very little. However firms with established research programs also markedly decreased research. In terms of the nature of research, the decline is most evident in high-quality publications. The implied value of scientific capability, as measured by stock market valuations or by the acquisition price in $\mathrm{M} \& \mathrm{~A}$ deals, also declined. By contrast, patenting by large American firms increased and the implied value of patents, including the premium paid for patents in M\&A, did not decrease. We find no evidence that invention became less science-intensive, or that the science used in inventions grew older. These patterns are present across a broad range of industries, except perhaps biotechnology.

As mentioned above, we are not the first to note the decline of many large corporate labs, or document that corporate scientists are publishing less (e.g., Coombs and Georghiou, 2002; Bhaskarbhatla and Hegde, 2013). Tijssen (2004), for instance, shows that the total number of papers published by corporate researchers in academic journals substantially declined over the period 1996-2001. Data from the National Science Foundation (NSF) also indicates that the share of basic and applied research in corporate $\mathrm{R} \& \mathrm{D}$ in the United States declined from 28 percent in 1985 to 21 percent in 2009. ${ }^{2}$ However, a limitation of both Tijssen's paper and the NSF statistics is that they present aggregate patterns. Thus, it is difficult to assess whether the trends they document reflect changes in the behavior of existing firms or other factors, such as a change in the industrial mix of reporting firms or the entry of innovative firms that do not engage in research. ${ }^{3}$

The first contribution of this paper is to distinguish between these effects, and quantify them. A second key contribution is to jointly analyze changes in both the value and the quantum of scientific outputs. By matching firm publications with stock market data as well as M\&A data, we are able to estimate the implied "value" of scientific capability. Previous work has argued that capabilities in research are plausible sources of competitive advantage (e.g., Gambardella, 1992, 1995; Durand et al., 2008). Griliches (1986) analyzed the drivers of productivity and profits for a sample of the 1,000 largest manufacturing firms in the U.S. For the period 1967-1977, he found that the share of basic research in the firm's R\&D expenditure was positively related to measures of productivity growth. Henderson and Cockburn (1994) showed that bundles of organizational practices capturing

\footnotetext{
${ }^{2}$ See NSF Science \& Engineering Indicators 2016, Appendix Tables 4.3, 4.4, 4.5.

${ }^{3} \mathrm{~A}$ second issue with NSF data is that distinguishing between research and development requires subjective judgments. Such judgments may not be fully reliable or consistent over time.
}

This article is protected by copyright. All rights reserved. 
pharmaceutical firms' propensity to connect with the external scientific community were strongly associated with success in drug discovery. Our results qualify these important early findings, as we show that for large firms in broad range of industries, the value attached to engaging in scientific research has declined over the last quarter of a century.

By estimating the implied value of scientific capability, we also probe the proximate causes of the decline of science in corporate R\&D. Large firms may be producing fewer scientific publications because (i) the private value of investments in internal (in-house) scientific research has declined, or (ii) its cost has increased. A third possibility is that firms have not reduced their investments in science: what has changed is their propensity to publish their research results in academic journals. We refer to this possibility as (iii) a change in publication practices. Though we cannot definitively rule out any of these possibilities, we argue that our findings, as well as aggregate NSF data, can most easily be reconciled with a reduction in the net future benefits from internal scientific research.

To summarize, our contribution is to go beyond case studies and aggregate data to document the extent to which corporate engagement in research has changed over time, within and across firms. Our findings suggest that, in reducing their engagement in science (as measured by firm publications), firms have been following market signals. Large firms are publishing less in scientific journals because these activities are now less privately valuable than they once were, as indicated by the collective judgement of investors and managers. This does not mean that research is not socially beneficial. Our evidence that invention is not becoming less science-intensive, or that the vintage of science used in inventions is not growing older, further suggests that the social value of science is not declining. We discuss, but do not empirically analyze, a variety of factors that might account for why the private value of science, for established firms, has diverged from the social value of science. In concluding the paper, we also discuss the implications of this reduction in corporate science for managers, as well as public policy.

\section{Conceptual background}

There is an extensive literature in strategy on corporate engagement in scientific research. Although many innovations arise through serendipity or through knowledge generated outside formal R\&D, corporations have also invested in science to accelerate the introduction of new products and processes. Innovations sometimes build directly on scientific advance (e.g., new drugs), and sometimes arise as indirect outputs of scientific research (e.g., laser). In other cases, scientific research enhances the productivity of technical search by guiding it toward more fruitful pastures (Evenson

This article is protected by copyright. All rights reserved. 
and Kislev, 1976; Gambardella, 1995; Fleming and Sorenson, 2004). Investments in scientific research also help firms absorb outside technology (Cohen and Levinthal, 1989; Gambardella, 1992). Company scientists can help identify promising new inventions, engage with the relevant outside researchers, and help assimilate and adapt outside technology. Publishing in academic journals and attending conferences, in particular, may be the most effective way to remain "plugged in" to the external scientific network (Rosenberg, 1990; Cockburn and Henderson, 1998). ${ }^{4}$

\subsection{Evolution of U.S. corporate research}

Corporate engagement in science began modestly. The leading American firms of the 1870s and 1880s, such as the railroad companies and Western Union, mostly relied on external inventions. They established industrial labs to evaluate the quality of these external inventions and other inputs (Hounshell, 1996; Mowery, 1995; Carlson, 2013). Growing competition, anti-trust pressures, and the increasing output of university-trained PhDs led companies such as GE and DuPont to invest in internal research to generate new products and processes (Reich, 1985; Hounshell and Smith, 1986). The process gained momentum during the inter-war years, as corporations grew larger and more anxious to control and "routinize" innovation. Landmark discoveries (e.g., vacuum tubes, radio, synthetic rubber, nylon), the growing practical applicability of recently discovered scientific principles, and the rapid increase in government funding in the United States led to more companies investing in internal research after World War II.

But corporate research did not always deliver satisfactory returns to shareholders. Discoveries such as nylon and the transistor were few and far between. And even when fundamental advances in science or technology were made, the sponsoring firms sometimes failed to profit from these advances, especially when the industries affected were unrelated to the sponsoring firm's core business. The graphical user interface, for instance, was invented in Xerox's PARC, but other firms, most notably Apple and Microsoft, reaped the rewards. By the 1980s, firms began to look to universities and small start-ups as sources of ideas and new products, using a mix of contracts, licenses, alliances, and outright acquisitions. Many corporate labs were closed, downsized, or redirected toward more commercial applications (Pisano, 2010).

NSF data indicate that firms with more than 10,000 employees accounted for 73 percent of non-

\footnotetext{
${ }^{4}$ Engaging in scientific activities also enhances the reputation of the firm and certifies the quality of its research to prospective investors, employees, government agencies, and sophisticated customers (Hicks, 1995; Audretsch and Stephan, 1996). Clinical studies, for instance, are routinely used by firms in the pharmaceutical industry to advertise the effectiveness of their drugs to doctors and hospitals (Azoulay, 2002). Also, to the extent that allowing employees to publish helps firms recruit more talented researchers, participating in the process of advancing science can be a profitable strategy for some firms (Stern, 2004; Roach and Sauermann, 2010).
} 
federally funded R\&D in 1985. By 1998, this share had dropped to 54 percent, and to 51 percent by 2008 (Mowery, 2009). A different indicator of the decline in the relative importance of large firms is the sharp drop in share of large firms in the R\&D 100 awards winners: whereas 41 percent of the awards went to Fortune 500 firms in 1971, only 6 percent went to Fortune 500 firms in 2006 (Block and Keller, 2009). Several factors contributed to the growing importance of small firms in R\&D. Encouraged by the 1980 Bayh-Dole act, universities began to patent and license actively, supplying inventions to both big firms and startups. University scientists found increasingly attractive to start their own businesses, whose high-powered incentives and nimble ways are difficult to replicate in large, established firms encumbered by bureaucracy (Christensen and Bower, 1996). Changes in the institutional and legal environment have complemented these trends. Start-ups can get financing from venture capitalists and SBIR and other government programs (Kortum and Lerner, 2000; Mazzucato, 2013). Intellectual property rights have been significantly strengthened starting from the early 1980s, first in the U.S. and subsequently in other countries (Jaffe and Lerner, 2004; Guellec and van Pottelsberghe de la Potterie, 2007).

These trends are consistent with a division of labor in which universities specialize in research, small start-ups convert promising new findings into inventions and larger, more established, firms specialize in product development and commercialization (Arora and Gambardella, 1994). In this view, smaller firms have a comparative advantage in generating inventions whereas larger firms have an advantage in exploiting them. Large firms may invest in scientific capability to be effective buyers of knowledge.

\section{Changing value of engaging in science: A taxonomy}

We follow Griliches (1981) and Hall (1993) in linking market value to research but use citationweighted publication stock, consistent with Gambardella (1992) and Cockburn and Henderson (1998). Hall et al. (2005) use a market-value approach to measure the return to R\&D investment for U.S. firms in the 1980s but do not distinguish between research and development. The literature also reports a positive relationship between the market valuation of firms and the science intensity of their patents (Deng et al., 1999) or their stocks of scientific publications (Simeth and Cincera, 2015).

These studies do not examine how the value of engaging in science has changed over time, or why. In this paper, we propose a parsimonious taxonomy to classify forces that may have affected the decision of large firms to withdraw from science, as measured by their propensity to publish 
in academic journals. A firm may publish less in academic journals because it has invested less in scientific research in the recent past or because it has become more reluctant to publish, for given research investments (a change in publication practices). Lower investments in research may result from a drop in the private benefits associated with research, or an increase in the private costs. Each of these outcomes has several possible drivers, which we discuss below. Our list is not exhaustive but does include most of the factors mentioned by academics and practitioners.

1. The private benefits of internal research have declined. There are a number of reasons why the benefits of investing in science internally may have declined in the past several years.

A. Science is becoming less useful to invention. Popular discussions sometime suggest that innovation has become less science-intensive. For instance, it is sometimes claimed that certain types of innovation (e.g., business methods, design innovations) or innovation in IT intensive industries largely do not build on scientific advances. As The Economist (2007) asserts: "One reason for the shift towards more commercially minded research in technology companies is that the nature of IT has changed so much. In [Vannevar] Bush's time the science that went into computing was itself closer to basic research. By contrast, many of the big scientific questions in computing have been answered - at least well enough for companies to find that innovation emerges from new ways of arranging today's technologies rather than inventing new ones. Dell's innovation was a business model that used extreme supply-chain efficiency to create bespoke computers. Likewise, Apple's iPod is a new interface atop standard industry parts". If true, this would imply that science has become socially less valuable, and overall investment in research should be lower. However, the idea that advances in information technology are not rooted in science is open to question. Not only do robotics, machine learning and artificial intelligence build upon statistics, computer science, electrical engineering, and material science, but advances in these technologies are also predicated upon advances in the underlying science, including engineering science.

B. Growth of technology markets. Even assuming that science has remained useful to invention, internal investments in research may have become less valuable because it is now easier than ever to tap into external sources of knowledge and invention. As discussed above, universities and small firms are now a more important source of inventions, and a thickening of that side of the market is likely to have reduced both the transaction cost of finding a suitable partner, and the monetary cost to be paid by a large firm for an externally sourced invention.

Several factors are likely to have further contributed to the growth of technology markets.

This article is protected by copyright. All rights reserved. 
Technology cycles are shortening, and it may be quicker, as well as less expensive, to rely on external capabilities. Greater protection of intellectual property rights has reduced the risk of expropriation in technology transactions. Developments in IT have rendered contracting for innovation easier and less expensive. The diffusion of online platforms (e.g., P\&G's Connect + Develop) and the growth of technology market intermediaries (e.g., yet2.com Marketplace, InnoCentive), for instance, are likely to have reduced transaction costs. Finally, managers may have become increasingly aware of the difficulties of managing research in large firms (Hounshell and Smith, 1986; Kay, 1988; Argyres and Silverman, 2004, Arora et al., 2014).

On the supply side, as already noted, universities are actively licensing their technologies, and nimble startups offer incumbents additional opportunities to acquire inventions instead of relying solely on internal research. This is consistent with the a growing division of innovative labor among established firms, start-ups, and universities (Jewkes et al., 1969; Arora et al., 2001). In a survey of over 6,000 manufacturing- and service-sector firms in the U.S., Arora et al. (2016) find that 49 percent of the innovating firms between 2007 and 2009 reported that their most important new product originated from an external source. Given that substitution of internal research inside large firms with externally sourced inventions is now arguably less costly, managers may find it increasingly hard to justify significant investments in science before investors.

\section{Growing appropriability problems: narrowing firm scope and increasing competition} and globalization. Because scientific results are difficult to protect through patents or other legal mechanisms, appropriability problems are particularly salient for research. In addition to a more rapid dissemination of scientific discoveries, two other trends may have contributed to exacerbate these problems: a decline in diversification at the firm level, and increased product market competition. Specialized firms are believed to have lower incentives to invest in scientific research because their narrower scope may impair their ability to recognize and exploit the commercial value of research results. In part, this originates from a natural tendency of both individuals and organizations to search locally (March and Simon, 1958; Stuart and Podolny, 1996). Firms are most likely to recognize and invest in opportunities that are related to their existing operations (Leonard-Barton, 1992; Ahuja and Lampert, 2001; Chesbrough, 2002). By contrast, diversified firms may be the ones best positioned to exploit the unpredictable outcomes of scientific research because, as Nelson (1959: 302) notes, "[a] broad technological base insures that, whatever direction the path of research may take, the results are likely to be of value to the sponsoring firm". Thus, as firms concentrate on their core markets, their private incentives to invest in scientific research may decline.

This article is protected by copyright. All rights reserved. 
Appropriability problems may have also become more serious because of increased product market competition. Theoretically, greater competition has ambiguous effects on the propensity of leading firms to develop innovations internally. On the one hand, competition drives pricecost margins down and thus discourages investments in $R \& D$, but on the other hand, successful innovation may be the only way to "escape" competition and low price-cost margins (Aghion et al., 2005). Empirical work on the topic, while extensive, has been largely inconclusive (see Cohen, 2010, for a survey). Bloom et al. (2016) use a panel of up to half a million firms over 1996-2007 across twelve European countries, and find that Chinese import competition led to increases in patenting, TFP, IT intensity and R\&D expenditures. Autor et al. (2016) reach the opposite conclusion. Using a sample of publicly listed U.S. manufacturing firms between 1975 and 2007, they find that firms more exposed to Chinese import penetration patent less. Both these papers focus on patents, which are more representative of innovation rather than scientific research, and also provide some protection from competition.

D. Increasing short-termism. Short-termism can be defined as a preference for actions that secure short-term benefits to the detriment of long-term results (Marginson and McAulay, 2008). Short-termism on the part of managers is often blamed on pressures by equity markets - in particular, investors' excessive focus on quarterly earnings and short-term stock price. While the evidence on this point is hardly conclusive (see, e.g., Woolridge and Snow, 1990), estimates suggest that only about 10 percent of institutional investors care about long-term performance and are informed ,about any individual company's fundamental long-term value (Bushee, 2004). ${ }^{5}$ Recent advances in information technology, such as higher frequency stock trading, may have intensified pressures from these "transient" investors (Bolton and Samama, 2013). Increasing M\&A activity may further exacerbate pressures on managers to deliver immediate results (Burgelman and McKinney, 2006; Valentini, 2012). As a result, some managers may cut research budgets to meet quarterly profit targets.

2. The private costs of internal research have increased. Reduced investments in internal scientific research may be driven not only by a reduction in benefits, but also by an increase in costs. We consider two possible sources of increasing costs.

A. Increase in salaries and equipment cost. The private costs of internal research relate to

\footnotetext{
${ }^{5}$ In 1960, the annual share turnover for firms listed in NYSE was 12 percent. By 1987, it had risen to 73 percent (Bratton, 2007). By 2010, the annual share turnover for firms listed in U.S. exchanges had reached 300 percent (Strine, 2010), implying an average holding period of just four months.
}

This article is protected by copyright. All rights reserved. 
the costs that firms must incur to set up and run their research facilities. A large component of these costs are the salaries that must be paid to corporate scientists and engineers. There is little evidence that PhDs' wages have increased in relative terms in the last few decades. Stephan (2012, Figure 7.2) compares the mean earnings of PhDs in engineering, physical sciences, and life sciences to the mean earnings of terminal baccalaureate recipients (the "average" educated person) between 1973 and 2006. With some variation, the PhD premium has remained relatively stable, at around 50 percent in engineering and 30 percent in the life sciences. However, because we cannot rule out that other costs have increased, we include changes in the private costs of internal research as a potential explanation for why firms' propensity to engage in science appears to be declining.

B. Decrease in scientific productivity of internal research. Another possibility is that internal research is less productive in terms of producing scientific output. This requires us to distinguish between research effort, scientific capability (as measured by publications), and inventions (as measured by patents). Over time, more research effort may be necessary to produce one unit of scientific output if producing scientific breakthroughs (or "climbing over the shoulders of giants" ) is getting harder. Note that a decrease in the scientific productivity of internal research is economically equivalent to an increase in the cost of producing publications. On the other hand, if innovation becomes less science based, then scientific effort is less relevant for producing inventions over time, implying a reduction in the benefit of investing in research.

3. Changes in publication practices. A firm may publish less in academic journals not because it is investing less in research, but because it has become more reluctant to publish. The decision to publish hinges on a balance between various costs and benefits. Benefits of disclosing R\&D results to the broader scientific community include: (i) strengthening ties with external researchers and institutions, (ii) reputational advantages and certification before various external stakeholders (investors, government, potential customers and partners), and (iii) potential benefits from providing a perk to internal scientists. The cost of disclosing research is chiefly that of detrimental spillovers to rivals.

The strengthening of intellectual property rights that started from the 1980s may have tilted the balance of costs and benefits. Publishing results too early might compromise a firm's ability to patent some of these results later. It may also enable rivals to patent some follow-on results. Potentially offsetting effects are also possible. Frequently firms embed the same piece of knowledge in both a patent and a paper - a patent-publication pair. Stronger intellectual property rights may 
then increase firms' incentives to publish because, through the associated patent, the risk of giving away knowledge is reduced. Thus, publication and patents may be complements, not substitutes (Gans et al., 2013).

If incentives within a corporation become more closely tied to patenting outputs, researchers will start devoting more time and effort to that activity, to the detriment of writing academic papers and publishing. Bhaskarbhatla and Hegde's (2013) study of changes in IP management practices at IBM is consistent with these ideas. In 1989, the reward system for scientists at IBM changed. Scientists had to earn 25-50 percent of their "points" through patents. This resulted in a large increase in patenting and a marked decline in "technical disclosures" by IBM, which contained incremental research findings not likely to be of great scientific significance. This suggests that, if greater emphasis on patenting is driving the decline in corporate publications, the type of publications most likely to be affected will be the ones closer to the applied research end of the spectrum. ${ }^{6}$

\subsection{Implications for the quantity and market value of scientific outputs}

Table 1 summarizes how the forces discussed above are likely to have changed firms' propensity to publish in academic journals and the market value associated with existing scientific capability (as proxied by a firm's publication stock). All these factors could lead to a drop in publications over time. They have, however, different implications for the market value of existing scientific capability.

In Appendix A, we formally show that a decrease in the benefits of research and an increase in its costs have opposite effects on the market value associated with existing scientific capability. A reduction in private benefits makes all internal research less valuable, and hence the value of existing internal scientific capability also drops in value. By contrast, an increase in the cost of internal research would reduce the propensity of firms to produce new scientific research, but that would raise the value of its substitute - the existing (and opportunely discounted) internal knowledge stock. Put differently, the more expensive it is to produce new science, the more valuable it is to already have a significant knowledge stock in-house.

It is conceivable that increases in disclosure costs imply a reduction in the value of the stock of publications, for instance, if investors see publication evidence of mismanagement. However, in line with our previous discussion, a greater cost of disclosure may increase the market value of the existing publication stock, because building a reputation for scientific capability becomes more

\footnotetext{
${ }^{6}$ During this time, IBM also changed research focus, requiring research units to become more commercially oriented. Consistent with this, the annual number of IBM publications in scientific journals also declined.
}

This article is protected by copyright. All rights reserved. 
costly, and the value of already having such a reputation is therefore higher.

[Insert Table 1 here]

\section{Data and results}

We combine data from four main sources: (i) U.S. Compustat, (ii) M\&A data from Thomson SDC Platinum, (iii) scientific publications from the Web of Science (previously known as ISI Web of Knowledge), and (iv) patent data from PatStat and the NBER 2006 patent data project. Our principal results pertain to publicly traded firms in the United States. We provide additional evidence using a large sample of M\&A deals. The latter sample is described in more detail later along with the corresponding empirical results.

Our principal sample consists of all firms from the U.S. annual Compustat database with positive R\&D expenditures and at least one patent for at least one year between 1980 and 2006. To better capture the complexity of large firms' innovative activities, which can be highly decentralized across subsidiaries, we construct the dataset at the ultimate-owner (UO)-parent-company level. Importantly, while the econometric analysis is performed at this level, the matching of patents and publications is done at the subsidiary level. For example, if a firm's subsidiary publishes scientific articles while the parent company is the assignee registered on the firm's patents, we capture both at the UO level.

The construction of the dataset presents several challenges. For instance, a parent company and a subsidiary may have different identification numbers and records within the Compustat data. Furthermore, a single company may correspond to multiple firm identifiers within the Compustat database due to changes in ownership structure and accounting changes over the sample period. We describe in detail the procedures we use to deal with these challenges in Appendix B.

These procedures leave us with 4,608 UO companies, which comprise our main sample of publicly traded companies in the United States. These firms have positive R\&D expenditures, at least one patent, and four consecutive years of data within Compustat, over the period 1980-2006. Our econometric analysis consists of an unbalanced panel 62,474 firm-year observations.

To capture a firm's participation in scientific research, we match our sample firms to the Web of Science database (previously known as ISI Web of Knowledge). We include articles from journals covered in the "Science Citation Index" and "Conference Proceedings Citation Index - Science", which exclude social sciences, arts and humanities articles. Using the affiliation field for each publications record, we identify 452,297 articles, published between 1980 and 2006, with at least 
one author employed by our sample of Compustat firms. We also match our sample firms to the patent datasets. Details on publication and patent matching are provided in Appendix B.

Using firm-level information on R\&D expenditures, publications and patents, we construct the corresponding stock measures. R\&D stock is calculated using a perpetual inventory method with a 15 percent depreciation rate (Hall et al., 2005). So the R\&D stock, $G R D$, in year $t$ is $G R D_{t}=$ $R_{t}+(1-\delta) G R D_{t-1}$ where $R_{t}$ is the R\&D expenditure in year $t$ and $\delta=0.15$. Publication stock in year $t$ is Publication stock $k_{t}=P u b_{t}+(1-\delta)$ Publication stock $k_{t-1}$ where Pub $b_{t}$ is the citation-weighted number of publications in year $t$. Citation weights are constructed as the ratio between the number of citations an article receives and the average number of citations received by all articles published in the same year. ${ }^{7}$ Patent stock is computed in a similar way using citation-weighted patent data. Yearly observations with missing values are set to zero.

Following Griliches (1986), market value is defined as the sum of the values of common stock, preferred stock, and total debt net of current assets. The book value of capital includes net plant, property and equipment, inventories, investments in unconsolidated subsidiaries, and intangibles other than R\&D. Table A1 in the online appendix lists the key variables used in this study, with the corresponding descriptions and data sources.

Table 2 summarizes descriptive statistics for our main sample firms. The mean market value of firms in our sample is $\$ 2$ billion. Mean R\&D spending is $\$ 69$ million and the mean stocks of scientific publications and patents are 149 and 188, respectively. 2,535 firms (55\% of our sample firms) publish a scientific article at least once during the sample period. Table A2 in the online appendix presents mean comparison tests for publishing versus non-publishing firms. Publishing firms are larger, have higher market value, and invest more in $\mathrm{R} \& \mathrm{D}$ than non-publishing firms.

\section{[Insert Table 2 here]}

Figures 1-2 plot how average annual publications and patents by the firms in our sample have changed over time. Later in the econometric analysis we present the within-firm analyses that account for changes in sample composition. Figure 1 shows that the average number of publications by publishing firms has dropped over time by approximately 60 percent. By contrast, the average number of patents has increased over time by about 100 percent. Figure 2 plots the average number of publications per year by industry. The same pattern of declining firm publications is evident across a wide range of industries. Section 4.1.3 shows that this pattern is robust to controlling for changes in sample composition over time.

\footnotetext{
${ }^{7}$ All our results hold whether or not we weight publications by citations.
} 


\section{[Insert Figures 1-2 here]}

\subsection{Econometric results}

\subsubsection{Number of publications over time}

We begin our analysis by examining how the number of publications produced by firms has changed over time. Table 3 presents the estimation results. The general pattern of results confirms that publications have fallen over time. Column 1 presents the results from a within-industry specification. The coefficient estimate on time trend is negative and statistically different from zero. This estimate implies that publications per year fell by 20 percent per decade, or by 52 percent over the complete estimation period. ${ }^{8}$ This fall is similar to that observed in Figure 1. Evaluated at the sample mean of 7 publications per year, the results imply that each firm published 0.14 fewer articles per year, assuming constant drop. Note however that firms who do not publish at all will register no decline. Column 2 restricts the sample to firms with at least one publication over the estimation period. As expected, the trend is more negative for publishing firms indicating a fall of close to 40 percent per decade, or about 0.6 fewer articles per year. In cumulative terms, and evaluated at the sample mean of 15 publications per year, this means that publishing firms, instead of producing 150 publications per decade, only produce 127. Aggregated over all firms, the implied reduction in scientific output becomes substantial.

The fall in publications over time can be the result of changes in sample composition, for instance, the entry of less research intensive firms entering the sample rather than a reduction in publications by existing research firms. To eliminate sample composition effects we turn to withinfirm specifications. As shown in column 3, the coefficient estimate on trend is much smaller in absolute value when controlling for firm fixed effects, indicating that a considerable part of the drop in publications over time from columns 1 and 2 is due to entry of less research-intensive firms. The estimate from column 3 implies that publications fell (within-firms) by about 20 percent per decade. This estimate is the average for all publishing firms in the sample, including new entrants for which within-firm variation might be limited. Column 4 includes only firms with at least one publication during the early sample period of 1980-1985 and also includes firm fixed effects. The coefficient estimate on time trend rises in absolute value to -0.25 , implying a reduction in the annual number of publications of about 25 per cent over the decade. The mean number of publications per year for established firms is 19. Thus, our findings imply that established firms published on average about

\footnotetext{
${ }^{8}$ The time trend is divided by 10 for all specifications (i.e., presented in decennial units).
} 
0.5 fewer articles per year, a drop in annual number of publications from about 19 to about 14 ten years later. In cumulative terms, instead of producing 190 publications per decade, these firms only produce 167.9

Columns 5-10 present the estimation results for the effect of trend by publication quality. We use two measures of publication quality: the impact factor of the journal where the article is published, and the number of scientific citations an article receives. The results show that the decline over time is largely due to a decline in high quality publications rather than publications in general. Columns 5-7 distinguish between high and low impact factor journals. In column 5 we include only publications in journals that fall into the bottom quartile of the journal impact factor distribution of the sample of firm publications. The coefficient estimate on trend is negative, but statistically indistinguishable from zero (an estimate of -0.02 with a standard error of 0.02). Column 6, including only publications in the top quartile of journal impact factor distribution, shows a large negative coefficient estimate on trend (an estimate of -0.32 with a standard error of 0.03 ), implying a 32 percent reduction in firm publications per year over the sample period. Restricting the sample to firms with established research programs (firms with at least one publication during the period 1980-1985) yields a decline of 35 percent by these firms in journals in the top quartile. Columns 8-10 use the number of scientific citations received by the publication, normalized by the mean number of citations received by all publications published in the same year as the focal publication, as a measure of quality. We distinguish between articles in the top quartile of all publications appearing in the same year (not just those by corporate scientists) and in the bottom quartile of all publications. The same pattern of results holds with this measure as well: the number of publications per year in the lowest quartile remained stable over time, yet highly cited publications declined by over a third over the sample period. Column 10 shows that the decline in highly cited publications is more marked in firms with established research programs. ${ }^{10}$

In summary, we find evidence consistent with a decline in corporate participation in research.

\footnotetext{
${ }^{9}$ The decline is especially pronounced for very large established firms. For instance, IBM publications steadily increased from 594 in 1981 to a peak of 1212 in 1992, and then fell steadily to 602 in 2006 . Over the same period, its patenting increased from 384 in 1980 to 853 in 1992 to 3626 in 2006 . The average annual decline for IBM from its peak is about 44 publications per year, while patenting increased by about 200 per year.

${ }^{10}$ We find that European firms have experienced a similar decline in publication activity. We match publication and patent records to all European firms from Amadeus (private and public firms). Lacking data on R\&D expenditures, we restrict attention to firms that either patent or publish at least once during the sample period 1997-2007, for which financial data are available. We identify about 58,000 publications by 3,642 firms and 210,000 patents by 10,053 firms. Table A3 presents the estimation results for within-firm changes in number of publications and patents. We observe a very similar pattern of results in the European sample. Publications decline over time after controlling for firm sales, at about the same rate for public and private firms (column 3). The rate of decline is similar when we restrict attention to firms that are present in the sample for longer than 10 years (column 4), and it is even greater when we focus only on firms that started publishing prior to 1980 (column 5).
} 
This decline cannot be explained solely by the entry of new types of firms that are less scienceintensive, though the latter is undoubtedly an important part of the explanation. Rather, the decline is present even in analyses that control for firm fixed effects. Further, the decline is more marked when we focus on firms with established research programs. Finally, consistent with the idea that corporations are shifting their focus from research to development, we find that the decline is largely confined to high quality publications.

\section{[Insert Table 3 here]}

\subsubsection{Market value of publication stock over time}

Changes in publication output could reflect either a reduction in the private benefits of internal research or an increase in its private marginal cost (or both). In the online appendix we provide a simple model which shows that an increase in marginal cost would reduce the quantity of research but increase the market value of the stock of research. By contrast, a decline in the private benefits of science will reduce both the quantity of research and the market value of the stock of research. Here, we empirically examine how the market value of the publication and patent stocks has changed over time. ${ }^{11}$ Specifically, we estimate a version of the well known Tobin Q equation, where we regress the $\log$ of market value on stocks of assets, including $\mathrm{R} \& \mathrm{D}$, patents, as well as publications (Griliches, 1981). The coefficient estimates from a Tobin Q type regression can be thought of as a "shadow price" of the corresponding tangible or intangible asset, under the assumption that a firm maximizes expected future profits but the assets cannot be adjusted costlessly. Using a log-log specification, as we do, implies that the coefficient estimates are elasticities. Each coefficient estimate can also be interpreted as the share of the value of the firm attributable to the corresponding asset (see Hall 1993 for details).

The results in Table 3 point to the importance of controlling for variation across firms. Accordingly, we focus on within-firm variation. Table 4 presents within-firm estimates where the dependent variable is the natural log of stock market value. To learn about how the value of scientific capability has changed over time, we include an interaction term between time trend and the natural log of publication stock. To ensure the trend effect are not driven by patents, we also include a similar interaction between patent stock and time trend.

Column 1 is our baseline specification without trend interaction. The elasticity of market value

\footnotetext{
${ }^{11}$ Since both types of shifts may have occurred, we are technically estimating the net quantitative impact of these shifts. That is, whether cost increases are quantitatively more important than a decline in private benefits in leading to the reduction in the annual number of publications.
}

This article is protected by copyright. All rights reserved. 
with respect to publication stock is 0.08 and statistically different from zero. Evaluated at the sample average, this elasticity implies that the market value of a publication is $\$ 1.1$ million $\left(0.08 \times \frac{2075}{149}\right)$.

Column 2 adds the time trend interacted with publication and patent stocks. The coefficient estimate on the trend interaction with publication stock is negative and statistically different from zero. The estimate indicates that elasticity of market value with respect to publication stock fell by about 20 percent per decade $(0.02 / 0.11)$, or by close to 50 percent over the estimation period. By contrast, the elasticity of market value with respect to patent stock shows no downward trend.

Column 3 includes only publishing firms, and column 4 includes only firms with established research programs (i.e., firms with at least one publication during the early sample period 19801985). In line with our previous results (Table 3), the decline is more marked for this type of firms. The coefficient estimates imply that the elasticity of publication stock fell by 50 percent per decade $(0.03 / 0.06)$ for all publishing firms and by 67 percent $(0.04 / 0.06)$ for firms with established research programs. Based on the estimates from column 4 and evaluated at the sample mean, the stock market value associated with one publication by a firm with an established research program is $\$ 900$ thousand $\left(0.06 \times \frac{4224}{286}\right)$ in the first decade of our sample $(1980-1990) .{ }^{12}$ By the end of second decade of our sample, this value drops by 67 percent to $\$ 295$ thousand $\left(0.02 \times \frac{4224}{286}\right)$. Thus, on average each publications adds about $\$ 60$ thousand less to firm value than it did the year before. The time trend estimates also imply a reduction in the value of scientific capability (holding publication stock constant) of $\$ 171$ million between the first and second decade of our sample $((0.9-0.3) \times 286))$. This decline appears reasonable in magnitude and substantial. In addition, these firms publish 25 percent fewer publications per decade (column 4 in Table 3). Evaluated at the sample average of 190 publications per decade, there are fewer 48 publications per firm-decade. Assigning a shadow price of $\$ 900$ (\$295) thousand per publication, this implies that the value attributable to scientific capability declined by $\$ 214(\$ 185)$ million per decade. ${ }^{13}$

Furthermore, the average stock market value of a firm with an established research program is $\$ 4.2$ billion with asset stock of $\$ 2.5$ billion. Thus, the intangible stock of those firms is $\$ 1.7$ billion. This suggests that, over the estimation period (2.6 decades), the market value attributable to scientific knowledge stock declined by between 28 to 32 percent of the market value of their intangible assets $(214 \times 2.6 / 1700$, or $185 \times 2.6 / 1700)$.

\footnotetext{
${ }^{12}$ The average stock market value and publication stock for firms with mature research programs are $\$ 4,224$ million and 286, respectively. The implied value of one publication is the estimated elasticity multiplied by the ratio of market value to the total stock of publications i.e., $0.06 \times \frac{4224}{286}$.

${ }^{13} \mathrm{~A}$ reduction in research is a sensible response to a reduction in its value. The part of the value of the firm that will be attributable to scientific capability will naturally fall as well.
} 
Columns 5 and 6 distinguish between high and low quality publications using the journal impact factor. Also in line with the results in Table 3, the estimates in columns 5 and 6 suggest that the decline in the elasticity of stock market value with respect to publication stock is driven by high quality publications. Column 5 includes separate stock variables for publications in high impact factor journals and for publications in low impact factor journals (classified based on top and bottom quartiles, respectively, as in Table 3). The estimates for high impact factor publications indicate that the elasticity estimate fell from 0.24 in 1980 (statistically different from zero) to zero in 2006.

To summarize, Table 4 suggests that, in withdrawing from science, large firms have been following market signals. The value of scientific capability, as measured by the correlation between stock market value and publication stock, has declined; moreover, this decline appears to be driven by high-impact research. Finally, based on our theoretical model, we conclude that the effects of a decrease in the private benefits of internal research are likely to have dominated the effects of a possible increase in the costs of research.

\section{[Insert Table 4 here]}

\subsubsection{Variation across industries}

Tables 5a and 5b examine how our main results vary across industries. We classify firms into industries based on their four-digit SIC level. The industries we consider are: drugs, chemicals, energy, telecommunications, machinery, electronics and energy. ${ }^{14}$

Table 5a examines how the number of publications varies over time in different industries, and Table 5b examines how the stock market value of publication stock also varies over time in these industries. Overall, we find that the trends reported in Tables 3 and 4 are present in most industries. In Table 5a, we estimate within-firm specifications for number of publications and allow the timetrend to differ across industries. Column 1 shows that publications fell in most industries except for drugs and energy, where the trend estimates are positive and statistically different from zero (e.g., for drugs: $-0.13+0.36=0.23)$. Column 2 includes only firms with at least one publication during the early sample period 1980-1985 and yields similar patterns.

Columns 3-4 estimate the specification from column 1 for publications in high impact factor journals (column 3) and low impact factor journals (column 4). We find that, in high impact factor journals, the decline in number of publications is evident in all industries, including drugs and energy. In low impact factor journals (column 4), there is no change in publications over time in

\footnotetext{
${ }^{14}$ Table A4 in the online appendix includes a list of all SIC codes that fall in each category.
} 
most industries, and there is actually an increase in drugs and energy.

Table 5b examines the relationship between scientific capability (measured by the stock of publications) and market value, over time in various industries. As in Table 4, it shows that the implied private value of scientific capability decreased in all industries except for drugs where the coefficient is insignificant. The principal conclusion from Tables $5 \mathrm{a}$ and $5 \mathrm{~b}$ is that the decline in high impact research that we have documented is broad based and not driven by any particular industry.

\section{[Insert Tables 5a and 5b here]}

\subsubsection{Value of scientific output in M\&A}

Our estimates of the private value of scientific capability rely upon stock market values. These reflect the collective judgment of investors. The price that firms pay to acquire other firms, and the part of the price attributable to the publication stock of the target, provide instead an estimate of the implied value that managers put on scientific capability. Using acquisition price to estimate the private value of scientific capability serves a second purpose as well. If the decline in publications merely reflected changes in the publication practices of the sample firms, but scientific capability remained valuable, one would not expect a large change in the value of the scientific capability of target firms. The acquisition price attributable to the publication stock of the target firm should remain stable, if even the acquiring firm did not intend to continue publishing in the future.

For this analysis, we use the set of acquisitions by our sample firms where data on acquisition price, percentage of acquired equity, value of assets, and annual sales is available in SDC Platinum. We further restrict the sample to targets from OECD countries. We match the acquired firms (targets) to ISI and PatStat to develop measures of the publication and patents of the target firms. Our sample includes 26,884 acquisitions by Compustat firms. Nearly half (46\%) of the deals involve American targets, 19 percent involve British targets, and 6 percent involve Japanese targets. At the time of their acquisition, 836 target firms have at least one scientific publication and 4,852 firms have at least one patent.

Table A5 in the online appendix summarizes the descriptive statistics for target firms. Target firms have a mean valuation of $\$ 155$ million, $\$ 75$ million in mean assets, and $\$ 133$ million in annual sales. Of the target firms that have at least one publication over the whole 1985-2007 sample period, the mean stock of publications at the time of the acquisition is 3 with a median value of 0.6. Of the target firms with at least one patent, the mean stock of patents (the sum of USPTO and EPO patents) at the time of the acquisition is 31 with a median value of 4 .

This article is protected by copyright. All rights reserved. 
Table 6 presents the estimation results for acquisition price as a function of stock of publications of the target. The estimation results are consistent with the stock market value regressions and show that the implied value of scientific capability has indeed fallen. Column 1 interacts publication and patent stocks with time trend. Consistent with our previous findings, the elasticity of acquisition price with respect to publication stock fell over time. On the other hand, the elasticity of acquisition price with respect to patent stock rose.

Columns 2-3 use more flexible specifications, which split the sample at the median year value. As before, the coefficient estimate on publication stock is very large and statistically significant in the early sample period (0.17) and falls nearly to zero in the later sample period (-0.04). We easily reject the null hypothesis that these two coefficients are statistically identical. Interestingly, there is no change in the implied value of tangible assets or patent stocks. Column 4 shows that the same pattern of results continues to hold when we restrict the sample to target firms that either patent at the USPTO or EPO or publish. Column 5 shows that the results are not driven by the 1999-2001 IT bubble.

The results in Table 6 indicate that the value acquiring firms place on the scientific capability of their targets (as proxied by publication stock) has fallen over time whereas the value they place on the technical capability of their targets (as proxied by patent stock) has not decreased. This is consistent with the idea that large firms are shifting their focus away from research and toward more applied activities. That is, acquiring firms appear to increasingly focus on commercializing the (patented) technologies of their targets, rather than carrying out further scientific research post-acquisition.

\section{[Insert Table 6 here]}

\subsubsection{Post-acquisition publication behavior}

If the value of scientific capabilities has declined and acquiring firms are becoming more reluctant to invest in science, we would expect to see a decline in publication activity by researchers of the target firms after the acquisition. Measuring post-acquisition publication activity is challenging because the acquired firm may cease to exist as an independent unit following the acquisition. To account for publications of potentially dissolved units, we include publications by acquiring firms in the post-acquisition period where the authors also appear on pre-acquisition publications belonging to the acquired firm. ${ }^{15}$ If large firms are withdrawing from science, then the scientists who are hired

\footnotetext{
${ }^{15}$ We use a three-year window to track publications after acquisition by the target firm. Around 90 percent of the publications continue to carry the name of the acquired firm, but about 10 percent of the post-acquisition publications
}

This article is protected by copyright. All rights reserved. 
through acquisitions should reduce their publication activity post-acquisition, and the reduction should be larger for more recent acquisitions.

Table 7 presents the estimation results of a within-firm variation in publication behavior postacquisition. For each firm, we examine a three-year window around the acquisition year and estimate the effect of a post-acquisition dummy - a dummy that receives the value of one for the three postacquisition years and zero for three pre-acquisition years. Columns 1-3 present the estimation results for the number of publications. Column 1 shows that publications tend to drop after the firm is acquired. Comparing columns 2 and 3, we see that the drop is concentrated in acquisitions in the second half of our sample period: the coefficient on the post-acquisition dummy fell from 0.01 for acquisitions between 1985 and 1996, to -0.20 for acquisitions between 1997 and 2004. The difference is statistically significant and meaningful. Whereas there was no decline in publication post-acquisition in the early part of the sample period, for later deals, after-acquisition publications dropped by about 33 percent of the sample mean. In unreported regressions, we confirm that the decline is more marked when publications are weighted by citations, where the citations are normalized by the mean citation for all publications in the same cohort.

We repeat this exercise, this time with patents. We check whether inventors from acquired firms also reduced patenting after acquisition. As we can see in columns 4-6, on average, patenting activity rose after the firm was acquired, although this rise took place mostly in the first half of the sample, while in the second half there was no change in patenting activity post-acquisition.

In sum, Table 7 provides additional support for the conjecture that large firms are withdrawing from engaging in scientific research internally. The firms they acquire have reduced their propensity to publish post-acquisitions, and this is true especially for acquisitions in the second half of our sample period.

\section{[Insert Table 7 here]}

\subsection{The use of science in invention}

Firms may reduce their engagement in science if scientific knowledge is becoming less relevant to commercial innovation. Tracing the application of science to commercial ends is very difficult. One proxy, admittedly highly imperfect, is the citations patents make to scientific publications (Narin et al., 1997). If corporate inventions are less likely to be science-based, there ought to be fewer citations to science by patents.

are in the name of the acquiring firm but with an author who appears on a previous publication of the target firm.

This article is protected by copyright. All rights reserved. 
Table 8 examines trends in the citations to scientific publications by patents produced by our sample firms. We start with the "non-patent literature" (NPL) referenced in patents. Because we are interested in patent citations to science, we purged the NPL of references to trade journals, product manuals, and the like, and retained only publications in "hard science" journals. As shown in column 1, patent citations to science as a share of all citations (patent and NPL) increased over time (within-firm estimation with controls for lagged R\&D stock and sales). Columns 2 and 3 split the sample into firms that publish and firms that do not. We find a positive trend effect for publishing firms and no effect for non-publishing firms. This suggests that, over time, absorptive capacity (as measured by publication activity) may have become more important to absorb and use existing scientific knowledge, the vast bulk of which is external to the firm.

Our findings are consistent with NSF data. NSF data show that whereas about 10.6 percent of U.S. utility patents cited scientific publications in 1998, the share had increased to 12 percent by 2008 (NSF S\&E Indicators, 2012, Table 5-49). More recent NSF data, using a different bibliometric database, show that in 2014, nearly 25 percent of patents cited scientific publications (NSF S\&E Indicators, 2016, Table 5-64). Note that this evidence refers to the use in patents of all published science (regardless of who sponsored it). Whether corporate science is becoming less useful to the corporations that sponsored it remains a topic for future research.

Though patents may continue to cite science, they may be citing older science. If innovation is less likely to require new scientific knowledge, firms may reduce their own investment in creating such new knowledge. Columns 4-5 present within-firm estimation results for specifications where the dependent variable is the natural log of the average publication age of cited articles for all patents of the focal firm in a given year. The age of cited publications is the difference between a patent grant year and the cited publication year. Average publication age of cited articles is computed for firm-year observations with at least one patent citation to science. The estimate of time trend is insignificant indicating that the age of science used in innovation has remained unchanged over time. Figure 3 plots the average publication age of cited articles. Results support the findings from column 4: the age of science used in innovation has remained unchanged with a mean age of approximately 10 years. Column 5 adds interactions between trend and industry dummies to explore cross-industry variation. Cited publication age remains stable over time except for drugs, where firms tend to cite somewhat older publications over time, perhaps reflecting the large investments in medical research in the United States since the early 1990s.

To sum up, we find no evidence that corporate inventions have become less science-intensive or This article is protected by copyright. All rights reserved. 
that the relevant scientific knowledge is of older vintage.

\section{[Insert Table 8 and Figure 3 here]}

\section{Discussion}

The main contribution of this paper is to provide a set of "stylized facts" that practitioners and researchers can use to inform future debates. Using data on all publicly traded American firms for over a quarter century, we find that publications by company scientists have declined between 1980 and 2007 in a broad range of industries. This is particularly true for publications that can be classified as "basic" or "influential". In stock market value regressions, we also find that the value attributable to scientific research has dropped, whereas the value attributable to technical knowledge (as measured by patents) has remained stable. We additionally analyze acquisitions of small, research-based firms to infer the implied value managers place on scientific capability in target firms, and examine the publication behavior of target-firm scientists following the acquisition.

Interpreted in conjunction with related evidence, both qualitative and quantitative, on the changing structure of corporate R\&D (e.g., Tijssen, 2004; Mowery, 2009; Bhaskarbhatla and Hegde, 2013), our findings indicate that large firms are withdrawing from internally engaging in science. The implications are potentially far-reaching. Previous research has documented the importance of scientific research to corporate value. In a classic paper, Griliches (1986) finds that firms that spent a larger fraction of their R\&D budgets on basic research were more productive in the 1970s.

He estimates a very large firm-level premium on basic research relative to total $\mathrm{R} \& \mathrm{D}$, on the order of 3 to 1 . Other scholars also highlight the importance for pharmaceutical firms to engage with the larger scientific community (Gambardella, 1992, 1995; Henderson and Cockburn, 1994, 1996; Cockburn and Henderson, 1998). They find that a bundle of organizational practices and firm characteristics - the propensity to promote scientific personnel on the basis of their standing in the scientific community, the proximity to research universities, firms' involvement in joint research projects and investment in information sources - was significantly related to success in drug discovery in the 1980s. Cohen et al. (2002) find that firms that engage with universities through a variety of channels, including conferences and meetings and informal exchanges, gain through new R\&D projects as well as completion of existing projects.

Our results qualify these important early findings. While we do find a positive association between scientific capability as measured by publication stock and firm value at the beginning of our sample period, this association largely disappears after the 1980s. To the best of our knowledge,

This article is protected by copyright. All rights reserved. 
no previous work has examined how the value of scientific capabilities has changed over time. Our results help make sense of observations such as the demise of the large industrial lab (Coombs and Georghiou, 2002) or the decline in firm publications (Tijssen, 2004; Bhaskarbhatla and Hegde, 2013). Further, our results suggest that, in implementing these policies, managers were correctly interpreting market signals. Indeed, another distinguishing feature of our work is that we jointly analyzed changes in both the value and the quantum of scientific outputs. By piecing together many complementary pieces of evidence, this paper provides the most comprehensive evidence to date on the changing structure of corporate R\&D in large firms.

To understand what forces drive the decline of large internal research efforts, we classify potential reasons into three broad categories: (i) a decline in the private value from internal research, (ii) an increase in the cost of research, and (iii) changes in publication practices. The first two categories encompass a variety of institutional, technological, and economic forces that may have induced large firms to reduce their investments in science. The third category, changes in publication practices, suggests that the decline in publication output may reflect not changes in the composition of large firms' R\&D efforts, but rather a rejection of "open science" in favor of greater secrecy.

We argue that changes in publication practices are unlikely to be the whole story for the decline in corporate publishing. Were it so, firms would disproportionately reduce publications that are close to the applied-science end of the spectrum, since these publications may contain commercially relevant and potentially sensitive information. We find instead that the decline in firm publications is most prominent for publications in high impact scientific journals, which arguably contain mostly basic rather than applied research. ${ }^{16}$ Furthermore, if changes in publication practices were simply due to changes in disclosure strategy but firms continued to value scientific capability to the same extent, we would not expect to find a significant reduction in the premium firms pay to acquire scientific capability through M\&A. Instead, we find that the premium for the scientific capability of firms acquired in M\&A has declined substantially. Finally, aggregate NSF data clearly show that the share of basic and applied research in total business R\&D expenditure has steadily declined as well, that business share of aggregate research has steadily fallen since the mid 1990s, and in absolute levels, business research has grown slowly in constant terms. ${ }^{17}$ This suggests that the decline in publications and the increase in patenting at the firm level are not merely driven by a change in publication strategy. Rather, large firms appear to be moving away from research and

\footnotetext{
${ }^{16}$ On the other hand, publications close to the applied-science end of the spectrum may be less at risk of exposing valuable knowledge if this knowledge has also been incorporated into patent applications.

${ }^{17}$ See Tables 4-3 to 4-8, Science and Engineering Indicators, 2016.
}

This article is protected by copyright. All rights reserved. 
toward development.

As mentioned above, large firms may be reducing their investments in internal science because the associated benefits are lower or the costs are higher. We develop a simple model that shows that these two sets of factors have similar effects on scientific output but opposite effects on the value of existing scientific capability. A decrease in benefits tends to reduce the value of existing scientific capability, while an increase in costs tends to increase its value. Indeed, the more expensive it is to create new knowledge, the more valuable it should be to already have a (opportunely discounted) knowledge stock in-house. In the empirical analysis, we document both a decline in the number of publications over time and a drop in the value of existing scientific capability. We conclude, tentatively at least, that the effect of a decrease in the private benefits of internal research dominates that of an increase in cost.

Among the mechanisms that may have affected the benefits of scientific research, we find little support for the idea that inventions have become less science-based, as measured by the citations patents make to scientific publications. We show that corporate inventions continue to draw upon science and that the vintage of scientific knowledge used in invention has not changed over time. ${ }^{18}$ We also find that engagement in science is becoming increasingly important to absorb and use existing scientific knowledge. It may well be that large firms are moving to a bare minimum of internal research expenditures that allow them to tap into externally generated knowledge. This is a delicate balancing act and very deep cuts in internal research may erode this capability irreversibly.

The paper highlights several promising areas for further research. Our framework suggests that the growth of technology markets, growing global competition and appropriability problems, and increasing short-termism are possible underlying causes of large firms' withdrawal from science. The relationship among these factors themselves is likely to be quite complex, as well as their relationship to corporate investment in science. For instance, globalization may induce multi-product firms to shed peripheral businesses, and more focused firms may then reduce their investments in science (Liu and Rosell, 2013). Competitive pressures may push firms to seek outside technologies, boosting technology markets but perhaps reducing the incentives for internal research.

Our emphasis on technology markets should also make clear that what we observe is a decline in large firms' engagement in in-house scientific research. Indeed, it is perfectly possible that large firms may be investing in science through other means; for instance, by funding scientists in

\footnotetext{
${ }^{18}$ We stress that what remains important for invention is the collective body of scientific knowledge that is produced over time. What is relevant for firms' investment decisions is the effect of their own research and publications on their own performance. In this paper we do not examine how the frequency of firms' patent citations to own science has changed over time, but this is an important direction for future work.
} 
universities or smaller ventures that are scientifically very active. ${ }^{19}$ A fuller account of all the ways in which large firms can invest, directly or indirectly, in science would be highly desirable.

Whether it is in the firms' long-run interest to reduce their investments in science is a difficult question. Markets appear to value such investments less, perhaps with good reason. Long-term investments in science may be less desirable with the growing availability of external inventions, or when competitive threats loom larger. A somewhat different view holds that, whereas in the past large American and European firms could afford to invest in long-term, speculative research, this is not possible because of impatient investors with short attention spans. Whether the pressures to meet investors' quarterly expectations are compromising valuable capabilities, or instead markets are pushing large corporations to efficiently outsource research to smaller, nimbler firms, is an important question that deserves further attention.

\section{Concluding remarks}

Our results indicate that the willingness of large firms to engage in internal scientific research has declined. This is reflected in their behavior (e.g., their propensity to publish), the acquisition price of the science-intensive firms they acquire, and the stock market premium that investors attach to scientific capability of the firms. It is also consistent with other evidence reported in the literature on the increase in alliances and licensing, as well as qualitative evidence on the decline in corporate research.

The paper has implications for how firms should manage their innovation activities, and raises some potential concerns about the future of U.S. innovation.

The implications for firms revolve around two fundamental questions in strategy - how firms can balance the tradeoff between current profitability and growth, and how they can access innovations cost-effectively. Our paper suggest that, because large firms are investing less in in-house research, they will have to rely more on inventions acquired from outside to fuel their growth. Indeed, Arora et al. (2016) document that nearly $50 \%$ of product innovations introduced by U.S. manufacturing firms relied upon external inventions. Though universities, start-ups and other technology specialists collectively supply only $17 \%$ of the total inventions, these are the highest value inventions. Clearly in an environment where external sources of innovation are more important, absorptive capacity and collaborative and integrative skills will also become more important, relative to the situation

\footnotetext{
${ }^{19}$ Our analysis does examine, however, the possibility that scientific capabilities may be acquired externally through mergers and acquisitions.
}

This article is protected by copyright. All rights reserved. 
when innovations largely arise from inside the firm (Burgelman and McKinney, 2006; Valentini, 2012).

A more extensive division of innovative labor will also create opportunities as well as challenges for scientific entrepreneurs. A key challenge is how to monetize scientific capability. If acquirers will not pay for scientific research, as our results indicate, start-ups will have to invest longer, until such time as the research bears fruit and the resulting innovations can be converted into patents and products. This will increase their costs and exposure to risk. Moreover, not all start-ups that are good at research are also good at converting their research into commercially relevant forms. Requiring all research-intensive start-ups to move downstream may dissuade some start-ups from investing in research, reducing the overall investment into an activity that is believed to have high social returns.

Our results may also raise some concerns about the future of U.S. innovation. The U.S. scientificindustrial complex has been a tremendous source of scientific and economic progress in the 20th century. The fact that one of its key components - the large corporate lab - is in decline can be seen as a reason for concern.

For a decline in internal scientific research by large firms not to adversely affect U.S. innovation and long-term prosperity, this decline must be compensated through other sources. The most obvious sources of new scientific knowledge, besides the large corporate labs, are universities and science-intensive start-ups. These institutions may in part be financed by large firms themselves, through licensing and contracts (Arora et al., 2001), corporate venture capital investments (Dushnitsky and Lenox, 2005), or outright acquisitions. ${ }^{20}$ Incorporating all these players into the analysis, as well as expanding its geographical scope to account for emerging economies such as China and India, are clearly priorities in future work.

But even assuming that research is being relocated from large labs to nimbler, more efficient organizations, reasons for concern may still remain. First, research conducted by universities and small firms may be an imperfect substitute for research conducted by larger firms. Commercialization of university research is subject to 'frictions', such as geographical isolation from the relevant industry actors (Belenzon and Schankerman, 2013; Bikard and Marx, 2015), that may hinder or delay technology transfer. Small firms' research may also qualitatively differ from large firms' research because small firms may lack the resources necessary to carry out certain types of projects, or may face stronger pressures to deliver results quickly (Tether, 1998; Kapoor, 2013). For instance,

\footnotetext{
${ }^{20}$ Arora et al. (2016) find that a third of all externally sourced inventions are sourced through licensing, contracts, and outright acquisitions.
}

This article is protected by copyright. All rights reserved. 
some projects require the integration of multiple knowledge streams and commercial capabilities that may only be available in large firms. Thus, small firms may be good at producing some types of innovations, but not at others (Pisano, 2010).

The best innovation ecosystems may also be those that emerge when large and small firms interact. Agrawal et al. (2014) find a large innovation premium in regions where numerous small labs coexist with at least one large lab, compared to regions of a similar size without many small labs or a large lab. One important reason appears to be the spin-off activity of large labs, suggesting the presence of significant positive externalities generated by large firms' research activities. The demise of the large corporate labs may compromise the vitality of many regional ecosystems.

Finally, as mentioned above, our results suggest that exit through acquisition is becoming a longer and more difficult process for scientific start-ups. This may dissuade some of them from entering their industries in the first place, reducing the overall investment in research and the innovation potential of the economy.

To conclude, innovation is a key source of modern economic growth. Over the last century, large, vertically-integrated firms have been the locus of much scientific and technological progress. However, although the literature has extensively documented how innovation has become more open, the associated shift away from internal research and toward development in large firms has largely been neglected. By documenting this under-studied but important trend, we contribute to the debate on how industrial innovation is changing and the implications for strategic management and policy. We hope future research will explore the underlying drivers of the trends we document, as well as their normative implications.

Acknowledgements: We thank four anonymous referees and the Editor, Anita McGahan, for very constructive comments that substantially improved the paper. We also thank Tim Bresnahan, Wes Cohen, Alfonso Gambardella, seminar participants at Barcelona GSE Summer Forum, Berkeley, BEROC Minsk, Copenhagen Business School, Harvard, London Business School, NBER Summer Institute and Stanford for helpful discussions. Lia Sheer provided excellent research assistance. All remaining errors are ours.

\section{References}

[1] Aghion P, Bloom N, Blundell RW, Griffith R, Howitt P. 2005. Competition and innovation: an inverted-U relationship. Quarterly Journal of Economics 120(2): 701-28.

This article is protected by copyright. All rights reserved. 
[2] Agrawal A, Cockburn I, Galasso A, Oettl A. 2014. Why are some regions more innovative than others? The role of small firms in the presence of large labs. Journal of Urban Economics 81: 149-165.

[3] Agrawal A, Cockburn I, Zhang L. 2015. Deals not done: sources of failure in the market for ideas. Strategic Management Journal 36(7): 976-986.

[4] Ahuja G, Lampert CM. 2001. Entrepreneurship in the large corporation: a longitudinal study of how established firms create breakthrough inventions. Strategic Management Journal 22(6-7): $521-543$.

[5] Argyres NS, Silverman BS. 2004. R\&D, organization structure, and the development of corporate technological knowledge. Strategic Management Journal 25(8-9): 929-958.

[6] Arora A, Belenzon S, Rios LA. 2014. Make, buy, organize: the interplay between research, external knowledge, and firm structure. Strategic Management Journal 35(3): 317-337.

[7] Arora A, Cohen WM, Walsh JP. 2016. The acquisition and commercialization of invention in American manufacturing: incidence and impact. Research Policy 45(6): 1113-1128.

[8] Arora A, Fosfuri A, Gambardella A. 2001. Markets for Technology: Economics of Innovation and Corporate Strategy. MIT Press: Cambridge, MA.

[9] Arora A, Gambardella A. 1994. The changing technology of technological change: general and abstract knowledge and the division of innovative labour. Research Policy 23(5): 523-532.

[10] Autor D, Dorn D, Hanson GH, Pisano G, Shu P. 2016. Foreign competition and domestic innovation: evidence from US patents. Working paper, Harvard University, Harvard Business School, Boston, MA.

[11] Azoulay P. 2002. Do pharmaceutical sales respond to scientific evidence? Journal of Economics $\&$ Management Strategy 11(4): 551-594.

[12] Belenzon S, Schankerman M. 2013. Spreading the word: Geography, policy, and knowledge spillovers. Review of Economics and Statistics, 95(3): 884-903.

[13] Bikard M, Marx M. 2015. Frictions in the flow of academic knowledge to industry: Evidence from simultaneous discoveries. Working paper, London Business School, London, UK.

[14] Bloom N, Draca M, Van Reenen J. 2016. Trade induced technical change? The impact of Chinese imports on innovation, IT and productivity. Review of Economic Studies 83(1): 87117.

[15] Bhaskarabhatla A, Hegde D. 2014. An organizational perspective on patenting and open innovation. Organization Science 25(6): 1744-1763.

This article is protected by copyright. All rights reserved. 
[16] Block F, Keller MR. 2009. Where do innovations come from? Transformations in the US economy, 1970-2006. Socio-Economic Review 7(3): 459-483.

[17] Bolton P, Samama F. 2013. Loyalty-shares: rewarding long-term investors. Journal of Applied Corporate Finance 25(3): 38-49.

[18] Bratton, WW. 2007. Hedge funds and governance targets. Georgetown Law Journal 95: 13752017.

[19] Burgelman RA, McKinney W. 2006. Managing the strategic dynamics of acquisition integration: lessons from HP and Compaq. California Management Review 48(3): 6-27.

[20] Bushee B. 2004. Identifying and attracting the "right" investors: evidence on the behavior of institutional investors. Journal of Applied Corporate Finance 16(4): 28-35.

[21] Carlson BW. 2013. Innovation and the modern corporation. From heroic invention to industrial science. In Companion Encyclopedia of Science in the Twentieth Century, Krige J, Pestre D (eds). Routledge: New York, NY; 203-226.

[22] Chesbrough H. 2002. Graceful exits and missed opportunities: Xerox's management of its technology. Business History Review 76(4): 803-837.

[23] Chesbrough HW. 2003. Open Innovation: The New Imperative for Creating and Profiting from Technology. Harvard Business School Press: Boston, MA.

[24] Christensen CM, Bower JL. 1996. Customer power, strategic investment and the failure of leading firms. Strategic Management Journal 17: 197-218.

[25] Cockburn IM, Henderson RM. 1998. Absorptive capacity, coauthoring behavior, and the organization of research in drug discovery. Journal of Industrial Economics 46(2): 157-182.

[26] Cohen WM. 2010. Fifty years of empirical studies of innovative activity and performance. In Handbook of the Economics of Innovation, Hall BH, Rosenberg N (eds). Amsterdam: NorthHolland; 129-213.

[27] Cohen WM, Levinthal DA. 1989. Innovation and learning: the two faces of R \& D. Economic Journal 99(397): 569-596.

[28] Cohen WM, Nelson RR, Walsh JP. 2002. Links and impacts: the influence of public research on industrial R\&D. Management Science 48(1): 1-23.

[29] Coombs R, Georghiou L. 2002. A new "industrial ecology." Science 296(5567): 471-471.

[30] Deng Z, Lev B, Narin F. 1999. Science and technology as predictors of stock performance. Financial Analysts Journal 55(3): 20-32.

[31] Durand R, Bruyaka O, Mangematin V. 2008. Do science and money go together? The case of the French biotech industry. Strategic Management Journal 29(12): 1281-1299.

This article is protected by copyright. All rights reserved. 
[32] Dushnitsky G, Lenox MJ. 2005. When do firms undertake R\&D by investing in new ventures? Strategic Management Journal 26(10): 947-965.

[33] Economist. 2007. Out of the dusty labs. The rise and fall of corporate R\&D. 1 March.

[34] Evenson RE, Kislev Y. 1976. A stochastic model of applied research. Journal of Political Economy 84(2): 265-281.

[35] Fleming L, Sorenson O. 2004. Science as a map in technological search. Strategic Management Journal 25(8-9): 909-928.

[36] Gambardella A. 1992. Competitive advantages from in-house scientific research: the US pharmaceutical industry in the 1980s. Research Policy 21(5): 391-407.

[37] Gambardella A. 1995. Science and Innovation: The US Pharmaceutical Industry During the 1980s. Cambridge University Press: Cambridge, UK.

[38] Gans JS, Murray FE, Stern S. 2013. Contracting over the disclosure of scientific knowledge: intellectual property and academic publication. NBER Working Paper No. 19560.

[39] Griliches, Z., 1981. Market value, R\&D, and patents. Economics Letters 7(2): 183-187.

[40] Griliches Z. 1986. Productivity, R\&D, and basic research at the firm level in the 1970s. American Economic Review 76(1): 141-154.

[41] Guellec D, van Pottelsberghe de la Potterie B. 2007. The Economics of the European Patent System: IP Policy for Innovation and Competition. Oxford University Press: New York.

[42] Hall BH, 1993. The stock market's valuation of R\&D investment during the 1980's. American Economic Review 83(2): 259-264.

[43] Hall BH, Jaffe A, Trajtenberg M. 2005. Market value and patent citations. Rand Journal of Economics 36(1): 16-38.

[44] Henderson R, Cockburn I. 1994. Measuring competence? Exploring firm effects in pharmaceutical research. Strategic Management Journal 15(S1): 63-84.

[45] Henderson R, Cockburn I. 1996. Scale, scope, and spillovers: the determinants of research productivity in drug discovery. RAND Journal of Economics 27(1): 32-59.

[46] Hicks D. 1995. Published papers, tacit competencies and corporate management of the public/private character of knowledge. Industrial and Corporate Change 4(2): 401-424.

[47] Hounshell DA. 1996. The evolution of industrial research in the United States. In Engines of Innovation: US Industrial Research at the End of an Era, Rosenbloom RS, Spencer WJ (eds). Harvard Business Review Press: Boston, MA; 51-56.

This article is protected by copyright. All rights reserved. 
[48] Hounshell DA, Smith JK Jr. 1986. Science and Corporate Strategy: DuPont REDD, 1902-1980. Cambridge University Press: New York.

[49] Jaffe AB, Lerner J. 2004. Innovation and Its Discontents: How Our Broken Patent System Is Endangering Innovation and Progress, and What to Do About It. Princeton University Press.

[50] Kapoor R. 2013. Persistence of integration in the face of specialization: How firms navigated the winds of disintegration and shaped the architecture of the semiconductor industry. Organization Science 24(4): 1195-2013.

[51] Kay N. 1988. The R\&D function: corporate strategy and structure. In Technical Change and Economic Theory, Dosi G, Freeman C, Nelson R, Silverberg G, Soete C (eds). Pinter: London, UK; 282-294.

[52] Kortum S, Lerner J. 2000. Assessing the contribution of venture capital to innovation. Rand Journal of Economics 31(4): 674-692.

[53] Lazonick W. 2013. The financialization of the U.S. corporation: what has been lost, and how it can be regained. Seattle University Law Review 36: 857-909.

[54] Leonard-Barton D. 1992. Core capabilities and core rigidities: a paradox in managing new product development. Strategic Management Journal 13(S1): 111-126.

[55] Liu R, Rosell C. 2013. Import competition, multi-product firms, and basic innovation. Journal of International Economics 91(2): 220-234.

[56] March JG, Simon HA. 1958. Organizations. Wiley: New York.

[57] Marginson D, McAulay L. 2008. Exploring the debate on short-termism: a theoretical and empirical analysis. Strategic Management Journal 29(3): 273-292.

[58] Mazzucato M. 2013. The Entrepreneurial State. Debunking Public vs. Private Sector Myths. Anthem Press: London, UK.

[59] Mowery DC. 1995. The boundaries of the U.S. firm in R\&D. In Coordination and Information: Historical Perspectives on the Organization of Enterprise, Lamoreaux NR, Raff DMG (eds). University of Chicago Press: Chicago; 147-182.

[60] Mowery DC. 2009. Plus ca change: industrial R\&D in the "third industrial revolution." Industrial and Corporate Change 18(1): 1-50.

[61] Narin F, Hamilton KS, Olivastro D. 1997. The increasing linkage between U.S. technology and public science. Research Policy 26(3): 317-330.

[62] Nelson RR. 1959. The simple economics of basic scientific research. Journal of Political Economy 67(3): 297-306.

This article is protected by copyright. All rights reserved. 
[63] Pisano G. 2010. The evolution of science-based business: innovating how we innovate. Industrial and Corporate Change 19(2): 465-482.

[64] Roach M, Sauermann H. 2010. A taste for science? PhD scientists' academic orientation and self-selection into research careers in industry. Research Policy 39(3): 422-434.

[65] Rosenberg N. 1990. Why do firms do basic research (with their own money)? Research Policy 19(2): 165-174.

[66] Simeth M, Cincera M. 2015. Corporate science, innovation, and firm value. Management Science 62(7): 1970-1981.

[67] Stephan PE. 2012. How Economics Shapes Science. Harvard University Press: Cambridge, MA.

[68] Stern S. 2004. Do scientists pay to be scientists? Management Science 50(6): 835-853.

[69] Strine L. 2010. One fundamental corporate governance question we face: can corporations be managed for the long term unless their powerful electorates also act and think long term? The Business Lawyer 66(1): 1-26.

[70] Stuart T, Podolny J. 1996. Local search and the evolution of technological capabilities. Strategic Management Journal 17: 21-38.

[71] Tether BS. 1998. Small and large firms: sources of unequal innovations? Research Policy 27(7): 725-745.

[72] Tijssen RJW. 2004. Is the commercialisation of scientific research affecting the production of public knowledge? Global trends in the output of corporate research articles. Research Policy 33(5), 709-733.

[73] Valentini G. 2012. Measuring the effect of M\&A on patenting quantity and quality. Strategic Management Journal 33(3): 336-346.

[74] Woolridge JR, Snow CC. 1990. Stock market reaction to strategic investment decisions. Strategic Management Journal 11(5): 353-363. 
Table 1. Factors that may have affected the propensity of large firms to publish

\begin{tabular}{|c|c|c|c|}
\hline \multicolumn{2}{|c|}{ Theoretical focus } & \multirow{2}{*}{$\begin{array}{ll} & \text { Reasons for change } \\
\text { - } & \text { Science has become less useful to innovation }\end{array}$} & $\begin{array}{l}\text { How factors have affected: } \\
\text { - Quantity of publications } \\
\text { - Value of existing publication stock }\end{array}$ \\
\hline \multirow{7}{*}{$\begin{array}{l}\text { Firms may publish less because they } \\
\text { have reduced their investments in } \\
\text { internal scientific research }\end{array}$} & $\begin{array}{l}\text { A. Changes in the private benefits } \\
\text { of internal research }\end{array}$ & & \multirow{5}{*}{$\begin{array}{l}\text { Quantity: } \\
\text { Value: }\end{array}$} \\
\hline & & - Growth of technology markets & \\
\hline & & $\begin{array}{l}\text { - Growing appropriability problems: increased } \\
\text { competition }\end{array}$ & \\
\hline & & - Growing appropriability problems: narrower firm scope & \\
\hline & & - $\quad$ Short-termism & \\
\hline & \multirow[t]{2}{*}{$\begin{array}{l}\text { B. Changes in the private costs of } \\
\text { internal research }\end{array}$} & $\begin{array}{l}\text { Rising wage costs for scientists, more expensive } \\
\text { equipment }\end{array}$ & \multirow{2}{*}{$\begin{array}{l}\text { Quantity: }- \\
\text { Value: } \quad+\end{array}$} \\
\hline & & - Decline in the scientific productivity of internal research & \\
\hline $\begin{array}{l}\text { Firms are increasingly reluctant to } \\
\text { disclose their scientific results to the } \\
\text { broader scientific community }\end{array}$ & $\begin{array}{l}\text { C. Changes in publication } \\
\text { practices }\end{array}$ & $\begin{array}{l}\text { - Stronger protection of IP rights has shifted firms' focus } \\
\text { on patenting, to the detriment of publishing }\end{array}$ & $\begin{array}{l}\text { Quantity: } \\
\text { Value: }\end{array}$ \\
\hline This article is protected by copyright. All righ & $\mathrm{s}$ reserved. & & \\
\hline
\end{tabular}




\begin{tabular}{lccccccc}
\hline \hline & & & & & \multicolumn{3}{c}{ Distribution } \\
\cline { 5 - 8 } Variables & No. Obs. & No. Firms & Mean & Std. Dev. & $10^{\text {th }}$ & $50^{\text {th }}$ & $90^{\text {th }}$ \\
\hline Market value (\$, mm) & 62,474 & 4,608 & 2,075 & 7,488 & 5 & 106 & 3,438 \\
Assets $(\$, \mathrm{~mm})$ & 62,474 & 4,608 & 1,212 & 4,200 & 1.44 & 38 & 2,142 \\
Sales $(\$, \mathrm{~mm})$ & 62,474 & 4,608 & 1,731 & 5,799 & 2 & 82 & 3,373 \\
R\&D expenditures (\$, mm) & 62,474 & 4,608 & 69 & 256 & 0 & 5 & 103 \\
Publication stock & 36,999 & 2,535 & 149 & 1,037 & 0 & 1 & 112 \\
Number of publications & 36,999 & 2,535 & 13 & 73 & 0 & 0 & 14 \\
Patent stock & 62,474 & 4,608 & 188 & 1,291 & 0 & 5 & 175 \\
Number of patents & 62,474 & 4,608 & 19 & 120 & 0 & 0 & 24 \\
\hline
\end{tabular}

Notes: This table presents summary statistics for the main variables used in the estimation for our sample of Compustat firms. Publication and patent variables are weighted by citations. Weights are the ratio between the number of citations received and the average number of citations received by publications (patents) published (granted) in the same year as the focal publication (patent). Publications are reported for firms with at least one publication during our sample period.

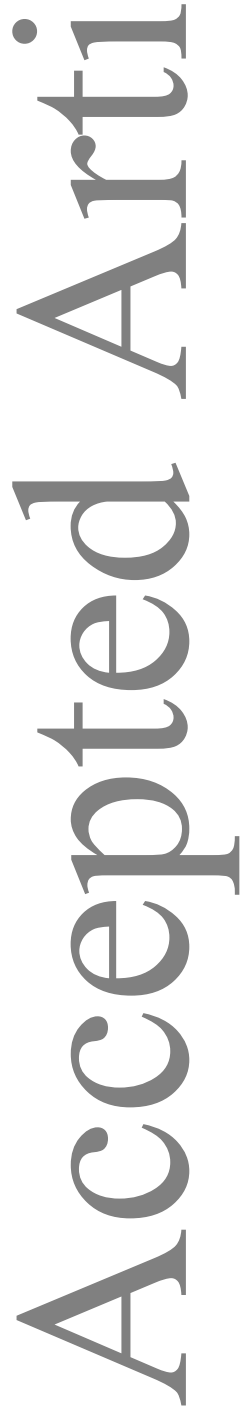


Table 3. Trend in number of publications, 1980-2006

\begin{tabular}{|c|c|c|c|c|c|c|c|c|c|c|}
\hline \multicolumn{11}{|c|}{ Dependent variable: $\ln ($ Number of publications $)$} \\
\hline & (1) & (2) & (3) & (4) & (5) & (6) & (7) & (8) & (9) & (10) \\
\hline Sample: & \multicolumn{4}{|c|}{ All journals } & \multicolumn{3}{|c|}{ Journal impact factor } & \multicolumn{3}{|c|}{ Scientific citations received } \\
\hline Variables & All firms & $\begin{array}{l}\text { At least } \\
\text { one pub }\end{array}$ & $\begin{array}{c}\text { Firm fixed } \\
\text { effects }\end{array}$ & $\begin{array}{l}\text { Established } \\
\text { research firms }\end{array}$ & $\begin{array}{l}\text { Bottom } \\
\text { quartile }\end{array}$ & Top quartile & $\begin{array}{l}\text { Established } \\
\text { research } \\
\text { firms, top } \\
\text { quartile }\end{array}$ & $\begin{array}{l}\text { Bottom } \\
\text { quartile }\end{array}$ & Top quartile & $\begin{array}{c}\text { Established } \\
\text { research firms, } \\
\text { top quartile of } \\
\text { citations }\end{array}$ \\
\hline Time trend (per decade) & $\begin{array}{l}-0.20 \\
(0.01)\end{array}$ & $\begin{array}{l}-0.38 \\
(0.02)\end{array}$ & $\begin{array}{l}-0.20 \\
(0.02)\end{array}$ & $\begin{array}{l}-0.25 \\
(0.03)\end{array}$ & $\begin{array}{l}-0.02 \\
(0.02)\end{array}$ & $\begin{array}{l}-0.32 \\
(0.03)\end{array}$ & $\begin{array}{l}-0.35 \\
(0.01)\end{array}$ & $\begin{array}{l}-0.08 \\
(0.02)\end{array}$ & $\begin{array}{l}-0.14 \\
(0.03)\end{array}$ & $\begin{array}{l}-0.18 \\
(0.03)\end{array}$ \\
\hline $\ln (R \& D \text { expenditures })_{\mathrm{t}-1}$ & $\begin{array}{c}0.42 \\
(0.02)\end{array}$ & $\begin{array}{c}0.49 \\
(0.02)\end{array}$ & $\begin{array}{c}0.23 \\
(0.02)\end{array}$ & $\begin{array}{c}0.24 \\
(0.03)\end{array}$ & $\begin{array}{c}0.12 \\
(0.02)\end{array}$ & $\begin{array}{c}0.03 \\
(0.01)\end{array}$ & $\begin{array}{c}0.04 \\
(0.01)\end{array}$ & $\begin{array}{c}0.09 \\
(0.01)\end{array}$ & $\begin{array}{c}0.12 \\
(0.02)\end{array}$ & $\begin{array}{c}0.13 \\
(0.02)\end{array}$ \\
\hline $\ln (\text { Sales })_{\mathrm{t}-1}$ & $\begin{array}{l}0.01 \\
(0.01)\end{array}$ & $\begin{array}{l}0.04 \\
(0.01)\end{array}$ & $\begin{array}{l}0.07 \\
(0.01)\end{array}$ & $\begin{array}{c}0.12 \\
(0.02)\end{array}$ & $\begin{array}{c}0.08 \\
(0.01)\end{array}$ & $\begin{array}{c}0.05 \\
(0.01)\end{array}$ & $\begin{array}{c}0.12 \\
(0.01)\end{array}$ & $\begin{array}{c}0.07 \\
(0.01)\end{array}$ & $\begin{array}{c}0.10 \\
(0.02)\end{array}$ & $\begin{array}{c}0.17 \\
(0.03)\end{array}$ \\
\hline Firm fixed effects & No & No & Yes & Yes & Yes & Yes & Yes & Yes & Yes & Yes \\
\hline Industry dummies & Yes & Yes & - & - & - & - & - & - & - & - \\
\hline Mean publications per year & 7 & 15 & 15 & 19 & 7 & 6 & 8 & 2 & 17 & 22 \\
\hline $\mathrm{R}^{2}$ & 0.53 & 0.6 & 0.87 & 0.89 & 0.70 & 0.77 & 0.79 & 0.82 & 0.79 & 0.82 \\
\hline Observations & 55,751 & 25,992 & 25,992 & 16,320 & 25,992 & 25,992 & 16,320 & 25,992 & 25,992 & 16,320 \\
\hline
\end{tabular}

Notes: This table presents within-firm estimation results for number of publications by publicly listed R\&D-performing American firms for the period

1980-2006. Columns 4, 7 and 10 include firms with at least one publication during the early sample period of 1980-1985. Columns 5-10 distinguish between

high quality and low quality scientific publications as indicated by the impact factor of the journal where they are published and the number of citations they

receive from other publications (normalized by average number of citations received by all publications published in the same year). Top and bottom quartile values are from all Web of Science publications. Trend is divided by 10 (i.e., presented in decennial units). Standard errors (in brackets) are robust to arbitrary heteroskedasticity through clustering by firms. 
Table 4. Trends in the stock market value of publications, 1980-2006

\begin{tabular}{|c|c|c|c|c|c|c|}
\hline & $(1)$ & $(2)$ & (3) & (4) & (5) & (6) \\
\hline \multicolumn{7}{|c|}{ Dependent variable: $\ln ($ Market value $)$} \\
\hline Variables & Baseline & $\begin{array}{c}\text { Trend } \\
\text { interactions }\end{array}$ & $\begin{array}{l}\text { At least } \\
\text { one pub }\end{array}$ & $\begin{array}{c}\text { Established } \\
\text { research } \\
\text { firms }\end{array}$ & All & $\begin{array}{c}\text { Established } \\
\text { research } \\
\text { firms }\end{array}$ \\
\hline Time trend $\times \ln (\text { Publication stock })_{\mathrm{t}-1}$ & & $\begin{array}{l}-0.02 \\
(0.01)\end{array}$ & $\begin{array}{l}-0.03 \\
(0.01)\end{array}$ & $\begin{array}{l}-0.04 \\
(0.01)\end{array}$ & & \\
\hline $\begin{array}{l}\text { Time trend } \times \ln (\text { Top quartile publicatio } \\
\text { stock })_{\mathrm{t}-1}\end{array}$ & & & & & $\begin{array}{l}-0.09 \\
(0.01)\end{array}$ & $\begin{array}{l}-0.09 \\
(0.02)\end{array}$ \\
\hline publication stock $)_{\mathrm{t}-1}$ & & & & & $\begin{array}{l}0.05 \\
(0.01)\end{array}$ & $\begin{array}{l}0.05 \\
(0.02)\end{array}$ \\
\hline Time trend $\times \ln (\text { Patent stock })_{\mathrm{t}-1}$ & & $\begin{array}{c}0.01 \\
(0.01)\end{array}$ & $\begin{array}{l}-0.01 \\
(0.01)\end{array}$ & $\begin{array}{c}0.01 \\
(0.01)\end{array}$ & $\begin{array}{c}0.01 \\
(0.01)\end{array}$ & $\begin{array}{c}0.01 \\
(0.02)\end{array}$ \\
\hline $\ln (\text { Publication stock })_{\mathrm{t}-1}$ & $\begin{array}{c}0.08 \\
(0.02)\end{array}$ & $\begin{array}{c}0.11 \\
(0.02)\end{array}$ & $\begin{array}{c}0.06 \\
(0.02)\end{array}$ & $\begin{array}{c}0.06 \\
(0.02)\end{array}$ & & \\
\hline n(Top quartile publication stock) $)_{t-1}$ & & & & & $\begin{array}{c}0.24 \\
(0.02)\end{array}$ & $\begin{array}{c}0.14 \\
(0.05)\end{array}$ \\
\hline $\mathrm{n}(\text { Bottom quartile publication stock })_{\mathrm{t}-1}$ & & & & & $\begin{array}{l}-0.05 \\
(0.02)\end{array}$ & $\begin{array}{l}-0.09 \\
(0.04)\end{array}$ \\
\hline $\mathrm{n}(1+\text { Patent stock })_{\mathrm{t}-1}$ & $\begin{array}{l}-0.01 \\
(0.02)\end{array}$ & $\begin{array}{l}-0.05 \\
(0.01)\end{array}$ & $\begin{array}{l}-0.03 \\
(0.02)\end{array}$ & $\begin{array}{l}-0.03 \\
(0.02)\end{array}$ & $\begin{array}{l}-0.04 \\
(0.02)\end{array}$ & $\begin{array}{l}-0.02 \\
(0.04)\end{array}$ \\
\hline $\ln (R \& D \text { stock })_{\mathrm{t}-1}$ & $\begin{array}{c}0.03 \\
(0.02)\end{array}$ & $\begin{array}{c}0.03 \\
(0.01)\end{array}$ & $\begin{array}{l}-0.00 \\
(0.01)\end{array}$ & $\begin{array}{l}-0.02 \\
(0.02)\end{array}$ & $\begin{array}{c}0.03 \\
(0.01)\end{array}$ & $\begin{array}{l}-0.02 \\
(0.03)\end{array}$ \\
\hline $\ln (\text { Sales })_{\mathrm{t}-1}$ & $\begin{array}{c}0.10 \\
(0.02)\end{array}$ & $\begin{array}{c}0.10 \\
(0.01)\end{array}$ & $\begin{array}{c}0.15 \\
(0.02)\end{array}$ & $\begin{array}{c}0.26 \\
(0.03)\end{array}$ & $\begin{array}{c}0.10 \\
(0.01)\end{array}$ & $\begin{array}{c}0.26 \\
(0.05)\end{array}$ \\
\hline $\mathrm{n}(\text { Assets })_{\mathrm{t}-1}$ & $\begin{array}{c}0.18 \\
(0.02)\end{array}$ & $\begin{array}{c}0.17 \\
(0.01)\end{array}$ & $\begin{array}{c}0.17 \\
(0.02)\end{array}$ & $\begin{array}{c}0.23 \\
(0.03)\end{array}$ & $\begin{array}{c}0.17 \\
(0.01)\end{array}$ & $\begin{array}{c}0.24 \\
(0.04)\end{array}$ \\
\hline Time trend & & $\begin{array}{c}0.71 \\
(0.02)\end{array}$ & $\begin{array}{c}0.96 \\
(0.04)\end{array}$ & $\begin{array}{c}0.87 \\
(0.05)\end{array}$ & $\begin{array}{c}0.70 \\
(0.02)\end{array}$ & $\begin{array}{c}0.83 \\
(0.08)\end{array}$ \\
\hline Firm fixed effects & Yes & Yes & Yes & Yes & Yes & Yes \\
\hline Year dummies & Yes & No & No & No & No & No \\
\hline $\mathrm{R}^{2}$ & 0.83 & 0.82 & 0.85 & 0.87 & 0.82 & 0.87 \\
\hline Observations & 42,448 & 42,448 & 21,237 & 12,779 & 42,448 & 12,779 \\
\hline
\end{tabular}

Notes: This table examines the relationship between the stock market value of a firm and its publication and patent stocks. Column 4 includes firms with at least one publication during the early sample period of 1980-1985. Columns 5-6

distinguish between high quality and low quality scientific publications as indicated by the impact factor of the journal where they are published. Top and bottom quartile values are from all Web of Science publications. Trend is divided by 10 (i.e., presented in decennial units). Standard errors (in brackets) are robust to arbitrary heteroskedasticity through clustering by firms. 
Table 5a. Trend in number of publications by industry

\begin{tabular}{|c|c|c|c|c|}
\hline \multicolumn{5}{|c|}{ Dependent variable: $\ln ($ Number of publications ) } \\
\hline & $(1)$ & $(2)$ & (3) & $(4)$ \\
\hline Variables & All journals & $\begin{array}{c}\text { Established research } \\
\text { firms } \\
\end{array}$ & $\begin{array}{c}\text { Top quartile journal } \\
\text { impact factor } \\
\end{array}$ & $\begin{array}{c}\text { Bottom quartile } \\
\text { journal impact } \\
\text { factor }\end{array}$ \\
\hline Time trend & $\begin{array}{l}-0.13 \\
(0.03)\end{array}$ & $\begin{array}{l}-0.14 \\
(0.03)\end{array}$ & $\begin{array}{l}-0.17 \\
(0.02)\end{array}$ & $\begin{array}{c}-0.003 \\
(0.02)\end{array}$ \\
\hline \multicolumn{5}{|l|}{ Time trend $\times$ : } \\
\hline Dummy for Drugs & $\begin{array}{c}0.36 \\
(0.06)\end{array}$ & $\begin{array}{c}0.34 \\
(0.07)\end{array}$ & $\begin{array}{l}-0.11 \\
(0.05)\end{array}$ & $\begin{array}{c}0.40 \\
(0.06)\end{array}$ \\
\hline Dummy for Chemicals & $\begin{array}{c}0.03 \\
(0.06)\end{array}$ & $\begin{array}{l}-0.06 \\
(0.07)\end{array}$ & $\begin{array}{l}-0.08 \\
(0.06)\end{array}$ & $\begin{array}{l}-0.01 \\
(0.06)\end{array}$ \\
\hline Dummy for Telecommunications & $\begin{array}{c}0.09 \\
(0.07)\end{array}$ & $\begin{array}{l}-0.07 \\
(0.07)\end{array}$ & $\begin{array}{l}-0.11 \\
(0.08)\end{array}$ & $\begin{array}{c}0.09 \\
(0.07)\end{array}$ \\
\hline Dummy for Machinery & $\begin{array}{c}0.07 \\
(0.04)\end{array}$ & $\begin{array}{l}-0.02 \\
(0.04)\end{array}$ & $\begin{array}{l}-0.01 \\
(0.03)\end{array}$ & $\begin{array}{c}0.05 \\
(0.03)\end{array}$ \\
\hline Dummy for Electronics & $\begin{array}{c}0.02 \\
(0.04)\end{array}$ & $\begin{array}{l}-0.01 \\
(0.04)\end{array}$ & $\begin{array}{l}-0.08 \\
(0.04)\end{array}$ & $\begin{array}{l}-0.02 \\
(0.04)\end{array}$ \\
\hline Dummy for Energy & $\begin{array}{c}0.17 \\
(0.07)\end{array}$ & $\begin{array}{l}-0.15 \\
(0.08)\end{array}$ & $\begin{array}{l}-0.15 \\
(0.11)\end{array}$ & $\begin{array}{c}0.12 \\
(0.07)\end{array}$ \\
\hline $\ln (R \& D \text { expenditures })_{\mathrm{t}-1}$ & $\begin{array}{c}0.20 \\
(0.02)\end{array}$ & $\begin{array}{c}0.21 \\
(0.02)\end{array}$ & $\begin{array}{c}0.07 \\
(0.01)\end{array}$ & $\begin{array}{c}0.11 \\
(0.01)\end{array}$ \\
\hline $\ln (\text { Sales })_{\mathrm{t}-1}$ & $\begin{array}{l}0.04 \\
(0.01)\end{array}$ & $\begin{array}{c}0.06 \\
(0.01)\end{array}$ & $\begin{array}{l}0.03 \\
(0.01)\end{array}$ & $\begin{array}{c}0.02 \\
(0.01)\end{array}$ \\
\hline Firm fixed effects & Yes & Yes & Yes & Yes \\
\hline $\mathrm{R}^{2}$ & 0.86 & 0.88 & 0.76 & 0.70 \\
\hline Observations & 33,287 & 21,921 & 33,287 & 33,287 \\
\hline
\end{tabular}

Notes: This table examines time trends in number of publications across industries. Industry classification is based on fourdigit main SIC codes. Column 1 includes firms with positive publication stock. Columns 3 and 4 restrict the sample to highest and lowest quartile of journal impact factor value, respectively. Trend is divided by 10 (i.e., presented in decade units). Standard errors (in brackets) are robust to arbitrary heteroskedasticity through clustering by firms. 
Table 5b. Trends in the stock market value of publications by industry

\begin{tabular}{|c|c|c|c|c|c|c|}
\hline & $(1)$ & $(2)$ & (3) & (4) & (5) & $(6)$ \\
\hline \multicolumn{7}{|c|}{ Dependent variable: $\ln ($ Market value $)$} \\
\hline Variables & Drugs & Chemicals & $\begin{array}{l}\text { Telecomm- } \\
\text { unications } \\
\end{array}$ & Machinery & Electronics & Energy \\
\hline Time trend $\times \ln (\text { Publication stock })_{\mathrm{t}-1}$ & $\begin{array}{c}0.02 \\
(0.01)\end{array}$ & $\begin{array}{l}-0.08 \\
(0.01)\end{array}$ & $\begin{array}{l}-0.08 \\
(0.01)\end{array}$ & $\begin{array}{l}-0.03 \\
(0.01)\end{array}$ & $\begin{array}{l}-0.04 \\
(0.01)\end{array}$ & $\begin{array}{l}-0.10 \\
(0.02)\end{array}$ \\
\hline Time trend $\times \ln (\text { Patent stock })_{\mathrm{t}-1}$ & $\begin{array}{c}0.01 \\
(0.01)\end{array}$ & $\begin{array}{l}0.01 \\
(0.01)\end{array}$ & $\begin{array}{l}0.03 \\
(0.01)\end{array}$ & $\begin{array}{l}-0.01 \\
(0.01)\end{array}$ & $\begin{array}{l}-0.01 \\
(0.01)\end{array}$ & $\begin{array}{l}0.03 \\
(0.02)\end{array}$ \\
\hline $\ln (\text { Publication stock })_{\mathrm{t}-1}$ & $\begin{array}{c}0.01 \\
(0.02)\end{array}$ & $\begin{array}{c}0.13 \\
(0.02)\end{array}$ & $\begin{array}{c}0.02 \\
(0.02)\end{array}$ & $\begin{array}{c}0.02 \\
(0.02)\end{array}$ & $\begin{array}{l}-0.02 \\
(0.02)\end{array}$ & $\begin{array}{c}0.05 \\
(0.03)\end{array}$ \\
\hline $\ln (\text { Patent stock })_{\mathrm{t}-1}$ & $\begin{array}{c}0.05 \\
(0.03)\end{array}$ & $\begin{array}{c}0.03 \\
(0.02)\end{array}$ & $\begin{array}{l}-0.02 \\
(0.02)\end{array}$ & $\begin{array}{l}0.09 \\
(0.01)\end{array}$ & $\begin{array}{l}0.05 \\
(0.02)\end{array}$ & $\begin{array}{c}0.01 \\
(0.03)\end{array}$ \\
\hline Time trend & $\begin{array}{l}0.13 \\
(0.03)\end{array}$ & $\begin{array}{c}0.24 \\
(0.04)\end{array}$ & $\begin{array}{l}0.39 \\
(0.03)\end{array}$ & $\begin{array}{l}0.35 \\
(0.02)\end{array}$ & $\begin{array}{l}0.33 \\
(0.02)\end{array}$ & $\begin{array}{l}0.30 \\
(0.05)\end{array}$ \\
\hline $\ln (\text { Assets })_{\mathrm{t}-1}$ & $\begin{array}{l}0.45 \\
(0.02)\end{array}$ & $\begin{array}{c}0.44 \\
(0.02)\end{array}$ & $\begin{array}{l}0.35 \\
(0.02)\end{array}$ & $\begin{array}{l}0.43 \\
(0.01)\end{array}$ & $\begin{array}{l}0.40 \\
(0.01)\end{array}$ & $\begin{array}{c}0.32 \\
(0.04)\end{array}$ \\
\hline $\ln (R \& D \text { stock })_{\mathrm{t}-1}$ & $\begin{array}{c}0.32 \\
(0.02)\end{array}$ & $\begin{array}{c}0.03 \\
(0.01)\end{array}$ & $\begin{array}{l}0.20 \\
(0.01)\end{array}$ & $\begin{array}{l}0.18 \\
(0.01)\end{array}$ & $\begin{array}{l}0.23 \\
(0.01)\end{array}$ & $\begin{array}{l}-0.04 \\
(0.02)\end{array}$ \\
\hline $\ln (\text { Sales })_{\mathrm{t}-1}$ & $\begin{array}{c}0.13 \\
(0.01)\end{array}$ & $\begin{array}{l}0.26 \\
(0.03)\end{array}$ & $\begin{array}{l}0.26 \\
(0.02)\end{array}$ & $\begin{array}{l}0.18 \\
(0.01)\end{array}$ & $\begin{array}{l}0.22 \\
(0.01)\end{array}$ & $\begin{array}{c}0.34 \\
(0.04)\end{array}$ \\
\hline $\mathrm{R}^{2}$ & 0.77 & 0.84 & 0.65 & 0.78 & 0.75 & 0.83 \\
\hline Observations & 6,114 & 2,784 & 8,497 & 13,081 & 10,296 & 1,454 \\
\hline
\end{tabular}

Notes: This table examines time trends in the stock market value of publications across industries. Industry classification is based on four-digit main SIC codes. Publications and patents are weighted by citations. Trend is measured in decade units. Standard errors (in brackets) are robust to arbitrary heteroskedasticity through clustering by firms. 
Table 6. Value of publication stock of acquired firms

\begin{tabular}{|c|c|c|c|c|c|}
\hline \multicolumn{6}{|c|}{ Dependent variable: $\ln ($ Target's firm value $)$} \\
\hline & (1) & $(2)$ & (3) & (4) & (5) \\
\hline & All years & $\begin{array}{c}1985- \\
1997\end{array}$ & $\begin{array}{c}1998- \\
2007\end{array}$ & $\begin{array}{c}\text { Innovating } \\
\text { targets }\end{array}$ & $\begin{array}{l}\text { Excluding } \\
\text { IT bubble }\end{array}$ \\
\hline \multicolumn{6}{|l|}{ Time trend $\times \ln (\text { Publication stock })_{\mathrm{t}-}$} \\
\hline 1 & $\begin{array}{c}-0.02 \\
(0.005)\end{array}$ & & & $\begin{array}{c}-0.02 \\
(0.005)\end{array}$ & $\begin{array}{c}-0.02 \\
(0.005)\end{array}$ \\
\hline Time trend $\times \ln (\text { Patent stock })_{\mathrm{t}-1}$ & $\begin{array}{c}0.003 \\
(0.001)\end{array}$ & & & $\begin{array}{c}0.002 \\
(0.001)\end{array}$ & $\begin{array}{c}0.003 \\
(0.001)\end{array}$ \\
\hline $\ln (1+\text { Publication stock })_{\mathrm{t}-1}$ & $\begin{array}{c}0.29 \\
(0.06)\end{array}$ & $\begin{array}{c}0.17 \\
(0.04)\end{array}$ & $\begin{array}{l}-0.04 \\
(0.07)\end{array}$ & $\begin{array}{c}0.27 \\
(0.06)\end{array}$ & $\begin{array}{c}0.31 \\
(0.07)\end{array}$ \\
\hline$p$-value for difference in estimates: & \multicolumn{5}{|c|}{$p$-value $<0.01$} \\
\hline $\ln (1+\text { Patent stock })_{\mathrm{t}-1}$ & $\begin{array}{c}0.04 \\
(0.01)\end{array}$ & $\begin{array}{c}0.07 \\
(0.01)\end{array}$ & $\begin{array}{c}0.07 \\
(0.01)\end{array}$ & $\begin{array}{c}0.03 \\
(0.02)\end{array}$ & $\begin{array}{c}0.04 \\
(0.01)\end{array}$ \\
\hline $\ln ($ Assets $)$ & $\begin{array}{c}0.59 \\
(0.01)\end{array}$ & $\begin{array}{c}0.59 \\
(0.01)\end{array}$ & $\begin{array}{c}0.60 \\
(0.01)\end{array}$ & $\begin{array}{c}0.65 \\
(0.02)\end{array}$ & $\begin{array}{c}0.60 \\
(0.01)\end{array}$ \\
\hline $\ln ($ Sales $)$ & $\begin{array}{c}0.17 \\
(0.01)\end{array}$ & $\begin{array}{c}0.18 \\
(0.01)\end{array}$ & $\begin{array}{c}0.16 \\
(0.01)\end{array}$ & $\begin{array}{c}0.08 \\
(0.02)\end{array}$ & $\begin{array}{c}0.17 \\
(0.01)\end{array}$ \\
\hline Time trend & $\begin{array}{c}0.02 \\
(0.003)\end{array}$ & & & $\begin{array}{c}0.01 \\
(0.01)\end{array}$ & $\begin{array}{c}0.02 \\
(0.003)\end{array}$ \\
\hline $\begin{array}{l}\text { Two-digit industry dummies } \\
\text { Country target dummies } \\
\text { Acquisition year dummies }\end{array}$ & $\begin{array}{l}\text { Yes } \\
\text { Yes } \\
\text { Yes }\end{array}$ & $\begin{array}{l}\text { Yes } \\
\text { Yes } \\
\text { Yes }\end{array}$ & $\begin{array}{l}\text { Yes } \\
\text { Yes } \\
\text { Yes }\end{array}$ & $\begin{array}{l}\text { Yes } \\
\text { Yes } \\
\text { Yes }\end{array}$ & $\begin{array}{l}\text { Yes } \\
\text { Yes } \\
\text { Yes }\end{array}$ \\
\hline $\mathrm{R}^{2}$ & 0.65 & 0.68 & 0.63 & 0.65 & 0.66 \\
\hline Observations & 26,884 & 14,990 & 11,894 & 4,684 & 25,004 \\
\hline
\end{tabular}

Notes: This table examines the relationship between target's firm value and its publication and patent stocks. The sample includes all SDC Platinum deals with non-missing information on target firm value, assets, and sales. The sample period is 1985-2007. Column 4 includes only target firms with at least one patent or scientific publication. Column 5 excludes acquisitions made during the 1999-2001 IT bubble period. Standard errors (in brackets) are robust to arbitrary heteroskedasticity through clustering by firms. 
Table 7. Publications and patents by target firms in three-year window around acquisition year

\begin{tabular}{|c|c|c|c|c|c|c|}
\hline & $(1)$ & $(2)$ & (3) & $(4)$ & (5) & $(6)$ \\
\hline Dependent variable: & \multicolumn{3}{|c|}{$\ln ($ Number of publications $)$} & \multicolumn{3}{|c|}{$\ln ($ Number of patents $)$} \\
\hline Acquisition year: & All & $\begin{array}{c}1985- \\
1996 \\
\end{array}$ & $\begin{array}{c}1997- \\
2004 \\
\end{array}$ & All & 1985-1996 & 1997-2004 \\
\hline Post-acquisition dummy & $\begin{array}{l}-0.08 \\
(0.02)\end{array}$ & $\begin{array}{c}0.01 \\
(0.03) \\
\end{array}$ & $\begin{array}{l}-0.20 \\
(0.04) \\
\end{array}$ & $\begin{array}{c}1.17 \\
(0.47)\end{array}$ & $\begin{array}{c}2.04 \\
(0.63) \\
\end{array}$ & $\begin{array}{c}0.18 \\
(0.70) \\
\end{array}$ \\
\hline p-value for difference in estimates: & & $p-v$ & 0.01 & & $p$-valu & $e<0.01$ \\
\hline Firm fixed effects & Yes & Yes & Yes & Yes & Yes & Yes \\
\hline Mean publications/patents & 0.57 & 0.57 & 0.58 & 8.6 & 6.6 & 10.3 \\
\hline $\mathrm{R}^{2}$ & 0.87 & 0.90 & 0.82 & 0.95 & 0.91 & 0.97 \\
\hline Observations & 19,475 & 10,615 & 8,860 & 22,369 & 11,040 & 11,329 \\
\hline
\end{tabular}

Notes: This table reports the results of OLS regressions that examine publishing and patenting activity before and after being acquired. Post-acquisition dummy receives the value of one for observations where the year is later than the acquisition value and zero otherwise. We include observations in a three-year window from the acquisition year. Standard errors (in brackets) are robust to arbitrary heteroskedasticity through clustering by firms. 
Table 8. Use of science in invention: citations by patents to scientific publications

\begin{tabular}{|c|c|c|c|c|c|}
\hline & (1) & $(2)$ & (3) & (4) & (5) \\
\hline Dependent variable: & Shar & of NPL cito & tions & \multicolumn{2}{|c|}{$\begin{array}{c}\ln (\text { Age of cited } \\
\text { publications })\end{array}$} \\
\hline Variables & All firms & $\begin{array}{c}\text { Publishing } \\
\text { firms }\end{array}$ & $\begin{array}{c}\text { Non- } \\
\text { publishing } \\
\text { firms }\end{array}$ & $\begin{array}{c}\text { Positive } \\
\text { NPL }\end{array}$ & $\begin{array}{c}\text { Positive } \\
\text { NPL }\end{array}$ \\
\hline Time trend & $\begin{array}{c}0.05 \\
(0.01)\end{array}$ & $\begin{array}{c}0.08 \\
(0.02)\end{array}$ & $\begin{array}{c}0.01 \\
(0.01)\end{array}$ & $\begin{array}{l}-0.05 \\
(0.13)\end{array}$ & $\begin{array}{c}0.12 \\
(0.22)\end{array}$ \\
\hline \multicolumn{6}{|l|}{ Time trend $\times$ : } \\
\hline Dummy for Drugs & & & & & $\begin{array}{c}0.88 \\
(0.31)\end{array}$ \\
\hline Dummy for Chemicals & & & & & $\begin{array}{l}-0.07 \\
(0.38)\end{array}$ \\
\hline Dummy for Telecommunications & & & & & $\begin{array}{l}-0.61 \\
(0.37)\end{array}$ \\
\hline Dummy for Machinery & & & & & $\begin{array}{l}-0.22 \\
(0.28)\end{array}$ \\
\hline Dummy for Electronics & & & & & $\begin{array}{l}-0.56 \\
(0.26)\end{array}$ \\
\hline Dummy for Energy & & & & & $\begin{array}{l}-0.34 \\
(0.48)\end{array}$ \\
\hline $\ln (R \& D \text { stock })_{\mathrm{t}-1}$ & $\begin{array}{c}0.01 \\
(0.001)\end{array}$ & $\begin{array}{c}0.01 \\
(0.001)\end{array}$ & $\begin{array}{c}0.01 \\
(0.001)\end{array}$ & $\begin{array}{l}-0.002 \\
(0.010)\end{array}$ & $\begin{array}{l}-0.003 \\
(0.010)\end{array}$ \\
\hline $\ln (\text { Sales })_{\mathrm{t}-1}$ & $\begin{array}{c}0.01 \\
(0.001)\end{array}$ & $\begin{array}{c}0.01 \\
(0.001)\end{array}$ & $\begin{array}{c}0.003 \\
(0.001)\end{array}$ & $\begin{array}{c}0.02 \\
(0.01)\end{array}$ & $\begin{array}{c}0.02 \\
(0.01)\end{array}$ \\
\hline $\ln (N P L$ cites $)$ & & & & $\begin{array}{c}0.05 \\
(0.01)\end{array}$ & $\begin{array}{c}0.05 \\
(0.01)\end{array}$ \\
\hline Firm fixed effects & Yes & Yes & Yes & Yes & Yes \\
\hline $\mathrm{R}^{2}$ & 0.51 & 0.51 & 0.36 & 0.43 & 0.43 \\
\hline Observations & 55,751 & 33,287 & 22,464 & 18,333 & 18,333 \\
\hline
\end{tabular}

Notes: This table examines time trends in citations to scientific articles by patents for our Compustat sample of R\&D-performing firms for the period 1980-2006. Share of NPL citations (Columns 1-3) is the ratio between patent citations to scientific journals and the total number of citations the patent makes (NPL and non-NPL). Columns 4-5 examine the trend in average age of cited articles for the subsample of firms with patents that cite scientific articles. Age is the difference between the grant year of the citing patent and the publication year of the cited article. Trend is divided by 10 (i.e., presented in decennial units). Standard errors (in brackets) are robust to arbitrary heteroskedasticity through clustering by firms. 


\section{Figure 3: Use of science in innovation:}

\section{average age of science cited in patents}

\section{and average cites per patent, 1980-2006}

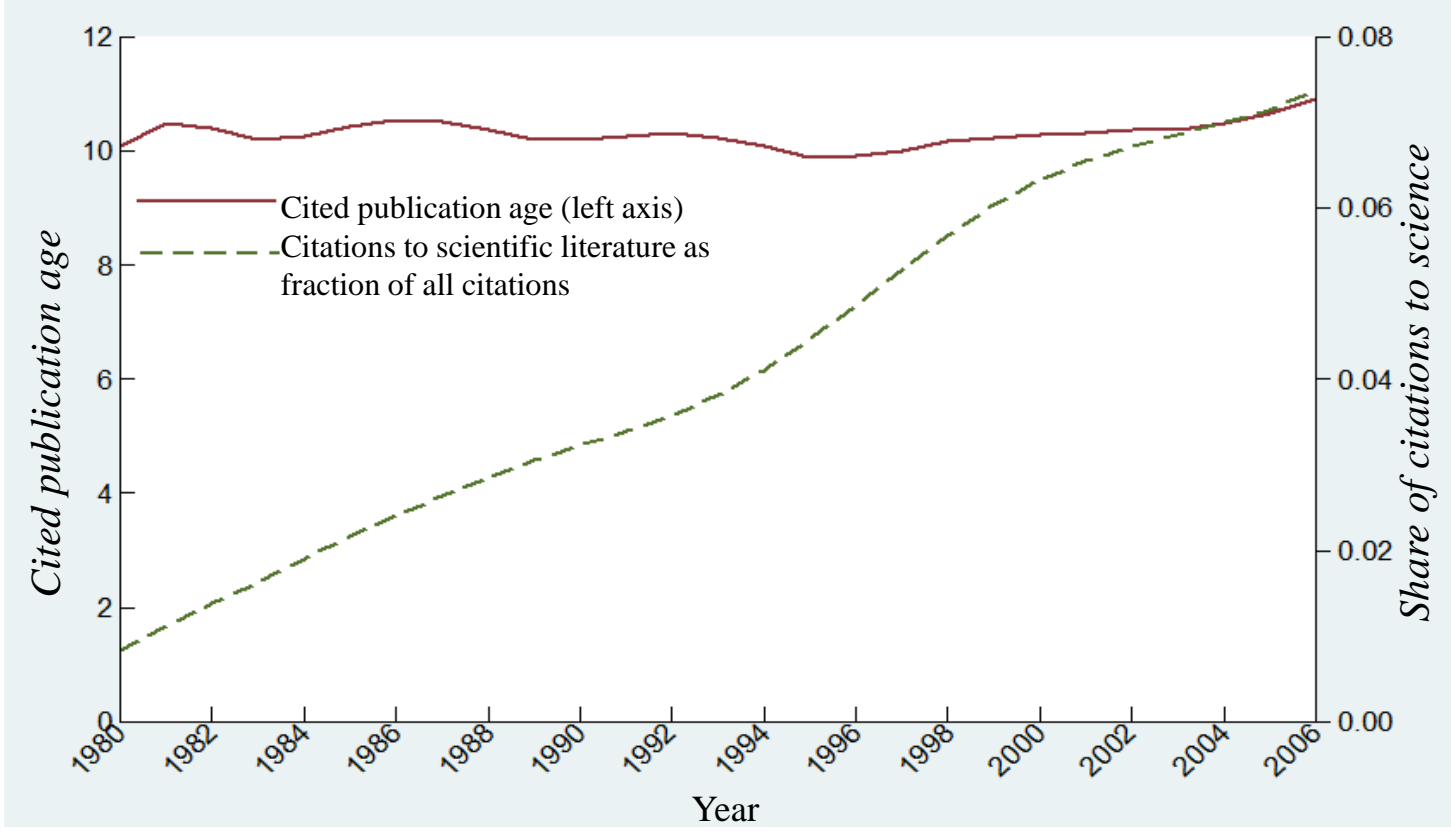

Note: This figure presents average publication age of cited articles by patents (NPL) and share of citations to science per firm-year for our sample firms. Cited publication age is the difference between patent grant year and year of publication of the cited article. Scientific citation share is the ratio between patent citations to leading scientific journals and the total number of references the patent makes. 